\title{
Health Monitoring of Civil Infrastructures by Subspace System Identification Method: An Overview
}

\author{
Hoofar Shokravi ${ }^{1, *(0)}$, Hooman Shokravi ${ }^{2}$, Norhisham Bakhary ${ }^{1,3}$, \\ Seyed Saeid Rahimian Koloor ${ }^{4}$ (D) and Michal Petrů ${ }^{4}$ (D) \\ 1 Faculty of Civil Engineering, Universiti Teknologi Malaysia, Skudai 81310, Malaysia; norhisham@utm.my \\ 2 Department of Civil Engineering, Islamic Azad University, Tabriz 5157944533, Iran; \\ hooman.shokravi@gmail.com \\ 3 Institute of Noise and Vibration, Universiti Teknologi Malaysia, City Campus, Jalan Semarak, \\ Kuala Lumpur 54100, Malaysia \\ 4 Institute for Nanomaterials, Advanced Technologies and Innovation (CXI), Technical University of \\ Liberec (TUL), Studentska 2, 46117 Liberec, Czech Republic; s.s.r.koloor@gmail.com (S.S.R.K.); \\ michal.petru@tul.cz (M.P.) \\ * Correspondence: hf.shokravi@gmail.com
}

Received: 27 March 2020; Accepted: 13 April 2020; Published: 17 April 2020

\begin{abstract}
Structural health monitoring (SHM) is the main contributor of the future's smart city to deal with the need for safety, lower maintenance costs, and reliable condition assessment of structures. Among the algorithms used for SHM to identify the system parameters of structures, subspace system identification (SSI) is a reliable method in the time-domain that takes advantages of using extended observability matrices. Considerable numbers of studies have specifically concentrated on practical applications of SSI in recent years. To the best of author's knowledge, no study has been undertaken to review and investigate the application of SSI in the monitoring of civil engineering structures. This paper aims to review studies that have used the SSI algorithm for the damage identification and modal analysis of structures. The fundamental focus is on data-driven and covariance-driven SSI algorithms. In this review, we consider the subspace algorithm to resolve the problem of a real-world application for SHM. With regard to performance, a comparison between SSI and other methods is provided in order to investigate its advantages and disadvantages. The applied methods of SHM in civil engineering structures are categorized into three classes, from simple one-dimensional (1D) to very complex structures, and the detectability of the SSI for different damage scenarios are reported. Finally, the available software incorporating SSI as their system identification technique are investigated.
\end{abstract}

Keywords: structural health monitoring (SHM); vibration-based damage detection; system identification; subspace system identification (SSI)

\section{Introduction}

In the recent years, there has been a considerable interest in "Smart City" concept and the monitoring, controlling, and preservation of the health state of critical infrastructures, like roads, buildings, bridges, and tunnels. Structural health is required to be diagnosed at every moment during a structure life cycle in order to provide high quality services. Civil engineering structures are designed for the lifetime of the occupants or facilities and their failure might lead to catastrophic consequences in terms of human life and economic assets [1]. Structural health monitoring (SHM) is one of the main 
stakeholders of the said Smart City concept [2]. SHM is an effective solution contributing to the need for safety, lowering the maintenance costs and reliable condition assessment of structures $[3,4]$.

SHM is an interdisciplinary subject that incorporates knowledge and experiences from synergetic technologies in civil, mechanical, control, and computer engineering to deal with the health assessment of structures. The health monitoring of structures has been the subject of many studies for the past three decades $[5,6]$. The development of a reliable SHM method for civil structures is a challenging task due to ambient-induced uncertainty and the associated complexity measures. Four analysis levels of damage detection are applied in the context of SHM that include: (1) detection, (2) localization, (3) quantification, and (4) prediction of the remaining life, whereas the first three levels are more explicitly reported in literature $[7,8]$.

Based on the acting load, SHM methods can be divided into two classes of static and dynamic-based methods [9]. The methods that use vibration characteristics of structures to assess the health state of structures, so-called vibration-based damage detection (VDD) $[10,11]$. The key premise of VDD is to estimate the modal parameters of a structure while using the analytical model that was constructed by system identification methods [12,13]. Static-based damage detection (SDD) methods rely on measuring the change in static response of structure, such as load bearing capacity, strain, deflection, and stiffness. Posenato et al. and Wu et al. [14] used strain data for damage detection of structure. Chen et al. [15] proposed a method to take advantages of stay cable force measurements and structural temperatures for damage detection. Yu et al. [16] used deflection data for damage identification in structures. Zhu et al. [17] introduced a temperature-driven method while using strain information of structures for anomaly detection.

Weigh in motion (WIM) is a widely used vehicle classification method for the health monitoring of structures. Bridge weigh in motion (BWIM) is a type of WIM technology that can identify traffic data, including speed, number of axles, axles spacing, and gross and axle weight of the passing vehicles using a series of conventional strain gauges. BWIM is particularly suitable for short-term measurements of traffic data, as it can be easily installed and detached from the bridge. Cardini and Dewolf [18] applied BWIM through using strain gauges to gain information on the quantity and weights of the trucks crossing highway bridges. Cantero et al. [19] proposed a BWIM-based damage identification method through introducing the concept of 'Virtual Axle' for deriving a damage indicator. Gonzalez and Karoumi [20] proposed a model-free damage detection method using deck accelerations response and BWIM. Kalyankar and Uddin [21] developed a three dimensional finite element model to estimate multi-vehicles-bridge interaction in a BWIM. The environmental factors are a weak point of vibrationand static-based damage detection [22]. However, in some cases, the temperature based methods shown higher sensitivity when compared to vibration based methods.

Estimations of the modal parameters in SHM are generally performed by system identification methods [23]. System identification is a mathematical procedure for establishing an analytical model based on experimental data. System identification is a mature field in SHM to extract modal parameters in VDD methods [24]. System identification methods in SHM can be classified into three categories based on their domains, including: time-domain (TD), frequency-domain (FD), and time/frequency domain (TFD) [25]. TD methods are more attractive for monitoring of civil structures, owing to the direct use of vibration signals. TD methods are generally classified within three groups of subspace system identification (SSI), natural excitation technique (NExT), and auto-regressive moving average (ARMA) [26]. The premise of the NExT method is that the response signals of a structure for ambient excitation and free-vibration have the same analytical form [27]. ARMA-based methods are popular statistical strategies for VDD of civil engineering structures. The auto regressive (AR) part ARMA models a linear function for the response time-history and the moving average (MA) section determines the moving average of the measurement response. The SSI algorithm presents a harmonious combination of algebraic, mathematical, statistical, and geometrical tools to identify the system parameters. SSI takes advantages of LS, angles between subspaces, QR decomposition, singular value decomposition (SVD), Kalman filter, and stochastic realization theory to deal with the 
problem of modal parameter identification. Subspace-based methods that are used for the parameter identification of civil structures are mainly one of the following two methods of data-driven subspace system identification (SSI-DATA) and covariance-driven subspace system identification (SSI-COV) approaches [28]. The ARMA model has the most similarity to the SSI-COV model, as both methods use the correlation function of the vibration measurement in their preprocessing stage.

Recently, a large number of subspace-based methods have been applied in VDD. However, the previously conducted surveys have not kept pace with the changing environment and diversity in this field. Therefore, there is a need for a review focusing on the most important recent studies conducted in the considered area. The presented review attempts to address the available studies that employed subspace-based techniques in VDD of civil structures. This paper provides an overview of the background and new findings in SSI with a focus on both theory and practice. In addition, it describes some contributions toward the development and application of the SSI algorithm in recent years.

This review study is organized, as follows. In Section 2, SHM methods are outlined and the strength and drawbacks of each class are highlighted. Section 3 evaluated vibration-based damage detection (VDD) methods. The focus is on subspace system identification in the three later sections (Sections 4-6). Section 7 introduces some commercially available software that use subspace as their main constituent. Future research directions and conclusions are provided in Sections 8 and 9, respectively.

\section{Structural Health Monitoring (SHM)}

An SHM system implements strategies for the damage detection of structures [29-31]. Currently, SHM is known as a well-established tool for the diagnosis of damages in civil engineering communities and it is employed in a number of different structures, such as buildings, bridges, and dams. Structural data are collected from several points through installed sensors and they are analyzed to evaluate the health of a structure. Figure 1 shows the categorization of SHM methods with a focus on addressing key subspace-based algorithms. SHM methods are divided into local methods, which mainly rely on non-destructive evaluation (NDE) strategies and global methods. Based on the incorporated domain, the VDD strategies could be categorized as TD, FD and TFD methods. The TD methods are generally from one of the auto-regressive moving average (ARMA), natural excitation technique (NExT), or subspace system identification (SSI) families. The SSI methods are an important class of algorithm and they can be divided into three categories of canonical variate analysis (CVA), numerical algorithms for state-space subspace system identification (N4SID), and multivariable output error state-space (MOESP). N4SID is of the most favored SSI algorithm in SHM due to its capability to cope with output-only data (stochastic, unknown input). Two classes of N4SID algorithms are commonly practiced in SHM of civil engineering structures, namely the SSI-DATA method and the SSI-COV method.

NDE is a local SHM method used to perform constrained random tests to diagnose the state and severity of the possible defects. Some NDE methods are concerned with measuring defects in steel components, whereas others are designed for concrete substructures. Several NDE methods are available to identify defects in steel structures such as the ultrasonic test (UT), radiographic test (RT) [32], and eddy current test (ET) [33]. UT is an acoustic NDE method that uses ultrasonic waves passing through a structure for detecting defects. The phased array ultrasonic test (PAUT) method is a more reliable type of UT that uses a greater number of arrays in order to reliably simulate a specimen's profile [33]. A variety of methods is applied for NDE of concrete components. These methods range from the very simple strength evaluation methods, such as using rebound hammer [34], to more complex methods, such as impact-echo [35] and radiography testing [36]. Even though local SHM methods yield excellent performance for detection and localization of damages, they have some limitations and drawbacks. The main disadvantage of these techniques is that the evaluation process cannot be implemented without any prior knowledge of the approximate damage location. Moreover, in many cases, access to below of the test area is an essential requirement that is not always affordable 
or practical [37]. Further detailed information on local SHM methods in civil engineering structures are provided in [38].

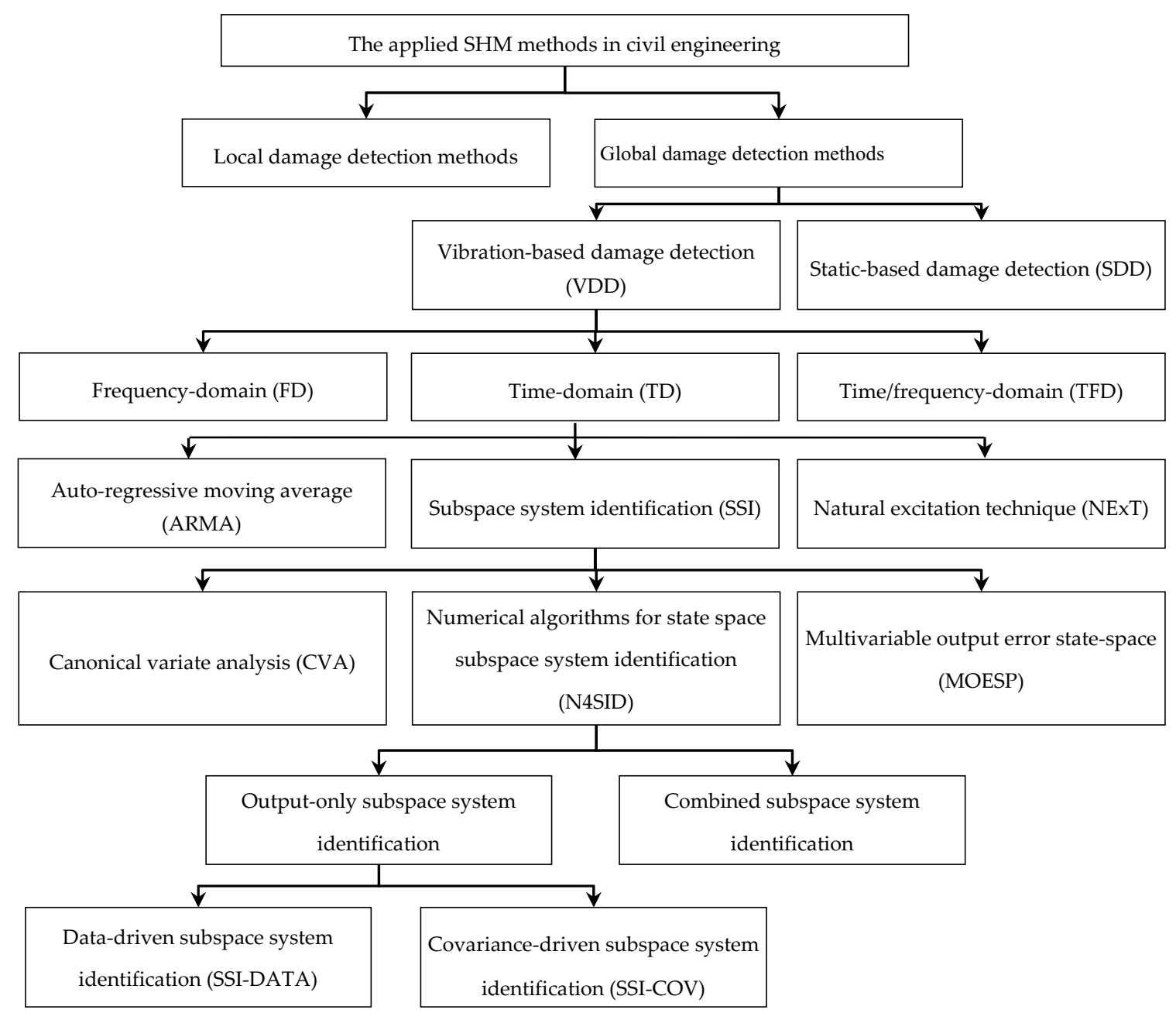

Figure 1. Classification of the structural health monitoring (SHM) methods with focus on subspace system identification (SSI) algorithm.

Researchers have proposed using global damage detection methods to identify damages in structures in order to overcome the previously mentioned limitations. Global methods are very effective choices to overcome the limitation of local SHM methods in civil engineering. In global methods, there is no limitation regarding the location of damage or even access to and preparation of the damaged area. These methods can localize and estimate the extent of damages while using the global characteristics of structures. The SDD methods require large measurement datasets for a reliable damage detection process. The targeted structure must generally be removed from its normal service in order to implement loading tests in SDD methods. Therefore, the SDD methods are not appropriate for continuous monitoring applications. When compared to VDD, the number of studies that employed SDD techniques are limited [39,40]. SDD methods are beyond the scope of this review paper and, for the sake of brevity, will not be covered in this study. A full review of the SDD has been well-documented elsewhere (for example [41]). VDD methods will be studied in the proceeding subsection.

\section{Vibration-Based Damage Detection (VDD)}

VDD is considered to be the most popular methodology in global SHM. VDD methods rely on changes in dynamic properties as an indicator of damage existence. These methods exploit observable 
variations in modal parameters, such as resonant frequency, damping, and mode shape or their derivative as indicators of change in physical properties of a structure. A thorough review of the system identification methods in VDD and modal analysis is provided in Song et al. [42] and Reynders [43].

\subsection{Frequency-Domain (FD) Methods}

An FD representation of a signal is extracted from a TD response signal using a Fourier transform. A Fourier transform describes a harmonic function by a linear combination of complex exponentials. A number of enhanced algorithms have been developed in order to improve the computational efficiency of Fourier transform, which are collectively termed as a fast Fourier transforms (FFT). FFT is generally used for deriving frequency response functions (FRF), and it plays the key role for many FD damage detection approaches [44]. FD methods in VDD can be classified into three main categories, which include [26]:

1. peak picking $(\mathrm{PP})$ methods;

2. complex mode indication function (CMIF) methods; and,

3. least squares complex frequency-domain (LSCF) methods.

PP methods, also referred to as basic frequency-domain (BFD), are the most typical approaches in modal testing and they initially rely on power spectral analysis and Fourier transforms. PP methods are qualitative in nature and founded upon the fact that FRF reaches an extreme approximately around the natural frequency. Furthermore, these methods could be accompanied with a half power bandwidth approach to extract damping ratio [45]. Frequency domain decomposition (FDD) is an accurate and simple technique for system identification that is widely used in modal analysis. FDD has been developed based on spectral density decomposition. The obtained spectra are a reduced form of a dynamic response for individual modes [46]. The enhanced frequency domain decomposition (EFDD) method is an extension of FDD for estimating reliable modal parameters [47].

CMIF methods can also be considered to be an extension of PP techniques. They have been widely used for the output-only identification of system parameters. CMIF is developed by performing SVD on a normal FRF matrix at each spectral line [48]. CMIF is combined with other algorithms to be used as a standalone model, such as the enhanced frequency response function (eFRF) and enhanced mode indicator function (EMIF). eFRF is the subsequent development of the CMIF method and it is used to estimate the frequencies that are associated with a particular peak in the CMIF [49]. The eFRF is rooted in the concept of physical coordinate transformation to enhance the estimation of modal parameters. EMIF could be considered as an extension of the CMIF/eFRF, which estimates modal parameters in several modes at one time. The distinctive property of this method is due to the fixity in the number of natural frequencies based on the peaks of CMIF plots.

LSCF is a fast and accurate method for estimating modal parameters. Originally, LSCF was applied to extract initial values in the maximum likelihood method. LSCF performs reliably due to its clear stabilization diagram [50]. The polyreference least-squares complex frequency-domain method (PolyMAX) is the polyreference version of the LSCF that takes advantage of the right matrix-fraction model. The main benefit of this method is that the closely spaced modal frequencies can be separated from each other [51]. El-Kafafy and Peeters [52] introduced the poly-reference least squares complex frequency-domain (pLSCF) for modal analysis. A two-step scheme is proposed to enhance the damping estimates. The proposed method can improve the processing time and accuracy of the modal identification, particularly for damping estimates.

FD methods are fast and accurate, but they suffer from some limitations in the frequency resolution of the estimated spectral data [53]. Conventional FD methods are not accurate and reliable for the analysis of non-linear and non-stationary signals. The resolution of the identified system parameters in low-frequency ranges or fewer numbers of incorporated modes is poor in these methods [54]. Moreover, the estimated damping coefficients are not accurate in the non-parametric FD methods [55]. 
The strong demand in the field of system identification to achieve higher accuracy and extract more information from the vibration responses led to the development of TD methods.

\subsection{Time-Domain (TD) Methods}

TD techniques rely on the fact that the vibrational properties of structures can be captured through the time-history response of a dynamic system. Hence, the extracted response in a healthy state is different from that of one that is in a damaged state. Figure 2 shows the schematic architecture of TD methods that were used for the identification of dynamic systems. Different numerical techniques, for example, FFT, SVD, least squares (LS), QR decomposition, Eigen-vector decomposition (EVD) [56], and statistical methods, were used to develop these algorithms. Observer/Kalman filter identification (OKID), NExT, and random decrement (RD) are the most common TD methods for extracting the FRF when there is no access to the input data. The input signal can be estimated using an auto-correlation or cross-correlation function [57].

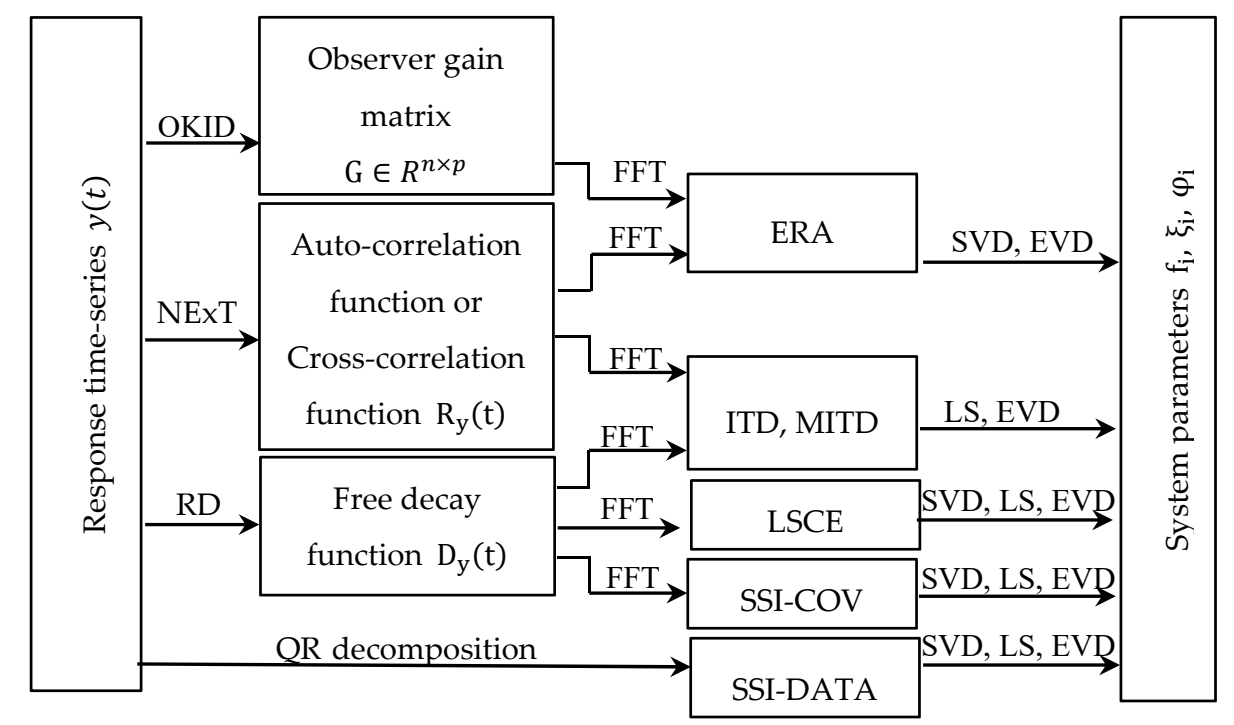

Figure 2. Schematic model for some of output-only time-domain modal identification methods.

The TD techniques in the health monitoring of civil structures can be classified into three widely known categories, which include [26]:

1. NExT methods;

2. ARMA methods; and,

3. SSI methods.

These methods are adopted for the identification of system parameters in civil engineering structures by introducing output-only extensions. NExT and SSI-COV methods are generally indirect where the SSI-DATA and ARMA methods are direct in nature, as can be seen in Figure 2. The TD methods are more appropriate for continuous monitoring compared to modal analysis methods due to direct use of response signals. Furthermore, the information extracted using TD methods is more complete than that of FD methods, particularly when a large number of modes or a large frequency range exist. A further explanation of the TD class of the identification methods are provided in the following subsections.

\subsubsection{Natural Excitation Technique (NExT) Methods}

James et al. [58] first proposed the NExT for the modal analysis of systems exposed to noise uncertainty. The key idea behind the NExT scheme is that the cross-correlation of the response signal from random excitation can be considered as a summation of decaying sinusoids. The complex 
exponential (CE) model is based on Prony's method and it was the first modal estimation method used as single-input single-output (SISO). The CE algorithm fits the curves of analytical impulse response into the experimental impulse response data [9]. The $\mathrm{CE}$ algorithm has been extended to the single-input multiple-output (SIMO) version by applying the LS technique. The algorithm was named the least-squares complex exponential (LSCE) [59]. The polyreference complex exponential (PRCE) is an extension of LSCE in the form of the multiple-input multiple-output (MIMO) identification of modal parameters [60].

Juang et al. [61] first proposed the Eigensystem realization algorithm (ERA) method for modal identification in the field of aerospace engineering. This method uses state-space forms together with Markov parameters in order to extract the coefficients of a dynamic system. Juang et al. [62] introduced an extension of ERA while using data correlations (ERA/DC). In the proposed method, the ERA realization-based approach is combined with a state-space correlation fit. The extracted modal parameters in this method are less sensitive to noise corruption and less prone to bias error. The improved polyreference complex exponential (IPCE) [63] is another extension to ERA and it is specifically designed for enhancing the reliability of PRCE and reducing the influence of random noise in modal identification. The IPCE technique uses correlation filtering as a pre-processing step to reduce the noise effects on measured data and minimize system order.

The Ibrahim time-domain (ITD) was of the first SIMO algorithms for estimating eigenvalues and eigenvectors in one-step. The ITD technique is reported not to be appropriate for heavy damped systems or systems with low natural frequencies [64]. The multiple references Ibrahim time-domain (MRITD) is an enhanced extension of ITD for MIMO modal analysis. The method is a high-resolution modal decomposition approach that is based on eigenanalysis [65]. OKID was originally a companion of the ERA, being denoted as OKID-ERA. The method suggested establishing a non-recursive LS observer to relate input and output data [66]. In recent years, the OKID has been introduced as a separate class of algorithms that could be combined with other models in a pairwise basis. Output-only ERA-OKID [67] and output-only observer/Kalman filter identification (O3KID) [68] methods are two recent versions of OKID for experimental modal analysis of civil engineering structures. The RD method is a TD approach for modal analysis through transforming system responses into random decrement functions [69]. RD functions are considered to be the free-vibration responses of a system. With the assumption of a zero-mean stationary Gaussian stochastic process, RD functions are proportional to correlation functions. The proposed method uses the concept of averaging to extract the random decrement signatures (RDS) of structures. Brincker [70] presented a general overview of the random decrement application in the modal analysis of structures. NExT methods provide a reliable tool for the modal identification of civil engineering structures. These methods have been implemented on several real world structures. However, the obtained results for damping ratios were less accurate that those that were obtained with other counterparts, such as the SSI and FDD algorithms [55].

\subsubsection{Auto-Regressive Moving Average (ARMA) Methods}

Auto-regressive moving average (ARMA)-based methods outperformed the purely statistical methods. The auto regressive (AR) part aims to model linear function time-history and the moving average (MA) part aims to determine the moving average of the time-series [71]. The general structure of the AR-based models depends on which of the $\mathrm{A}(\mathrm{q}), \mathrm{B}(\mathrm{q}), \mathrm{C}(\mathrm{q}), \mathrm{D}(\mathrm{q})$, and $\mathrm{F}(\mathrm{q})$ polynomials are used in the model. Equation (1) shows the general structure of AR-based models.

$$
A(q) y(t)=\frac{B(q)}{F(q)} u(t)+\frac{C(q)}{D(q)} e(t)
$$

Table 1 shows the most common ARMA models that were used in the system identification of civil engineering structures. 
Table 1. Common auto-regressive moving average (ARMA) models shown with their associated polynomials.

\begin{tabular}{cc}
\hline Used Polynomials & Name of Model \\
\hline $\mathrm{A}(\mathrm{q}), \mathrm{B}(\mathrm{q})$ & ARX \\
$\mathrm{A}(\mathrm{q}), \mathrm{B}(\mathrm{q}), \mathrm{C}(\mathrm{q})$ & Auto-Regressive Moving Average with eXogenous variable (ARMAX) \\
$\mathrm{A}(\mathrm{q}), \mathrm{C}(\mathrm{q})$ & ARMA \\
$A(q), B(q), D(q)$ & Auto-Regressive Auto-Regressive with eXogenous input (ARARX) \\
\hline
\end{tabular}

Several studies have been conducted while using autoregressive-based methods for the identification of damage in structures. Table 2 presents a review of applied ARMA methods in SHM and modal analysis with a focus on the test methods, damage features, and the incorporated pattern recognition techniques.

Table 2. Autoregressive-based methods applied in the structural health monitoring (SHM) of civil engineering structures.

\begin{tabular}{|c|c|c|c|}
\hline Method/Reference & Test Model & Damage Feature & Pattern Recognition \\
\hline AR [72] & $\begin{array}{l}\text { Progressive failure test of retrofitted } \\
\text { reinforced concrete bridge column }\end{array}$ & AR coefficients & X-bar control chart \\
\hline AR-ARX [73] & $\begin{array}{l}\text { Laboratory-scale 8- DOF } \\
\text { mass-spring system }\end{array}$ & $\begin{array}{l}\text { Residual error between } \\
\text { prediction and reference } \\
\text { signal }\end{array}$ & $\begin{array}{l}\text { Multi-paradigm statistical } \\
\text { pattern recognition }\end{array}$ \\
\hline ARMAV [74] & $\begin{array}{l}\text { Numerical model of a simply } \\
\text { supported beam and a real-size } \\
\text { steel-quake structure }\end{array}$ & $\begin{array}{l}\text { Changes in natural } \\
\text { frequency }\end{array}$ & $\begin{array}{l}\text { Confidence interval and } \\
\text { normal distribution of } \\
\text { random variables }\end{array}$ \\
\hline AR-ARX [75] & $\begin{array}{l}\text { A simulated three-story frame } \\
\text { structure }\end{array}$ & Residual errors & $\begin{array}{c}\text { Sequential Probability Ratio } \\
\text { Test (SPRT) }\end{array}$ \\
\hline VFAR [76] & $\begin{array}{l}\text { Numerical simulations of a six-story } \\
\text { shear building and a three-span } \\
\text { pre-stressed box-girder bridge }\end{array}$ & $\begin{array}{l}\text { Natural frequency and } \\
\text { damping ratio }\end{array}$ & - \\
\hline VBAR [77] & $\begin{array}{l}\text { Numerical model of a lumped mass } \\
\text { system and experimental model of a } \\
\text { steel cantilever beam }\end{array}$ & Natural frequency & - \\
\hline ARMAV [78] & Steel-quake structure & $\begin{array}{l}\text { Natural frequencies and } \\
\text { damping ratio }\end{array}$ & - \\
\hline TV-ARMAV [79] & $\begin{array}{l}\text { Supported beam with a moving } \\
\text { mass }\end{array}$ & $\begin{array}{l}\text { Natural frequencies and } \\
\text { mode shapes and damping } \\
\text { ratio }\end{array}$ & - \\
\hline ARMA [80] & $\begin{array}{l}\text { Analytical and experimental results } \\
\text { of the ASCE benchmark structure }\end{array}$ & First three AR components & $\begin{array}{c}\text { Multi-paradigm statistical } \\
\text { signal processing approach } \\
\text { combined with the pattern } \\
\text { classification }\end{array}$ \\
\hline ARMA [81] & $\begin{array}{l}\text { IASC-ASCE four-story } \\
\text { experimental benchmark structure, } \\
\text { Z24 bridge and the } \\
\text { Malaysia-Singapore Second Link } \\
\text { Bridge }\end{array}$ & Normalized AR coefficient & T-test statistical control chart \\
\hline ARMA [82] & $\begin{array}{l}\text { Simulated ASCE benchmark } \\
\text { structure }\end{array}$ & GMM & $\begin{array}{l}\text { Mahalanobis criterion } \\
\text { function }\end{array}$ \\
\hline ARIMA [83] & $\begin{array}{l}\text { Data from Malaysia-Singapore } \\
\text { Second Link bridge }\end{array}$ & $\begin{array}{l}\text { Coefficients of the ARIMA } \\
\text { model }\end{array}$ & Statistical outlier detection \\
\hline TARMA [84] & $\begin{array}{l}\text { Laboratory-scale steel beam with a } \\
\text { moving mass }\end{array}$ & Natural frequencies & - \\
\hline
\end{tabular}

The structures range from a very simple model of a mass spring system to more elaborate real world structures, as shown in Table 2. In many cases, the coefficients of the incorporated AR-based algorithm are directly used as damage features. For modal analysis, the extracted system parameters 
are utilized for the evaluation of dynamic behavior in a structure. Using modal parameters as damage features, the variation of the extracted parameters for the reference and actual state could be considered for the condition assessment of a structure. The obtained results for modal parameters are more robust when compared to other TD methods. However, higher scatterings in damping ratios are observed and the reported error is much more than other TD methods, such as SSI.

\subsubsection{Subspace System Identification (SSI) Methods}

Parametric TD methods provide a powerful and versatile mathematical framework for analyzing dynamic systems. Among all system identification methods, subspace-based techniques are the most remarkable achievement in the field of control and system identification. Meanwhile, many research studies on system identification have been concentrated on subspace methods in recent years. The subspace approach is a suitable technique for estimating the state-space model of a dynamic system. The SSI is a numerically reliable algorithm and it estimates models with good quality, particularly for multivariable systems $[85,86]$. The state-space form of the equation of motion can be written as Equation (2).

$$
\left\{\begin{array}{l}
x(t+1)=A x(t)+B u(t)+w(t) \\
y(t)=C x(t)+D u(t)+v(t)
\end{array}\right.
$$

where $x(t+1), u(t+1), x(t)$, and $u(t)$ are state vectors and scalars at time instant of $t+1$ and $t$, respectively. $\mathrm{y}_{\mathrm{k}}$ is output vector, $A, B, C$, and $D$ are system, control, output, and feedback matrices, respectively. $w(t)$ and $v(t)$ are measurement and process noise, respectively. Most subspace algorithms reported in the literature are closely related to the LS-based methods [87]. In the first step, an oblique projection is calculated and it is pre- and post-multiplied by appropriate weight matrices to infer the system order and state sequence. In the second step, a geometrical projection is adapted in order to eliminate the dependence of the SSI algorithm on future output. In the third step, LS is deployed to drive the A and C matrices. Finally, the Kalman predictor is used to estimate the system model by inferring the Kalman gain $\mathrm{K}$ of the state-space model. In a general sense, the most researched subspace methods in the field of system identification can be classified within the following three main categories [87]:

- CVA methods;

- MOESP methods; and,

- N4SID methods.

Larimore and Wallace [88] proposed CVA methods that are based on Markov parameters for TD system identification. The study continues with the same principles as the pioneering activities of Akaike [89] in a statistical setting. SVD is used as a tool to extract the incorporated canonical variates. Verhaegen [90] proposed the MOESP method for the identification of the multivariable state-space model from noisy input-output data. The MOESP subspace algorithm is known for two characteristics, those of the reduced-size Hankel matrix and the extended observability matrix. The method was not applicable for stochastic systems. Van Overschee and De Moor [91] unified proposed subspace schemes into a pragmatic approach, referred to as N4SID. The algorithm was analytically robust and reliable due to the use of SVD and QR decomposition. Based on the way, the subspace algorithm deals with the measurement time history data; they can be divided into the two categories of SSI-DATA and SSI-COV. In the next two subsections, a review on application of the SSI-DATA and SSI-COV algorithms in the SHM of civil engineering structures is outlined.

Data-Driven Stochastic Subspace Identification Method (SSI-DATA)

SSI-DATA is a method for identifying modal parameters by the direct use of measured response time-history [92]. Overschee et al. [93] introduced a subspace algorithm using power spectrum data. The state-space coefficients were derived using inverse discrete Fourier transform. The computational complexity in this method is higher when compared to that of direct subspace methods or FDD. 
Table 3 shows some examples of the methods that use SSI-DATA for damage detection and modal analysis.

Table 3. Some examples of schemes that use data-driven subspace system identification (SSI-DATA) in their damage identification process.

\begin{tabular}{|c|c|c|c|c|}
\hline Method/Reference & Damage Feature & Pattern Recognition & Test Model & Specification \\
\hline SSI-DATA [94] & Eigensolutions & $\begin{array}{l}\text { Statistical local } \\
\text { approach }\end{array}$ & Analytical model & Application of a combined SSI \\
\hline $\begin{array}{l}\text { Null-space based } \\
\text { algorithm [96] }\end{array}$ & $\begin{array}{l}\text { Residue matrix of } \\
\text { orthonormality } \\
\text { between subspaces }\end{array}$ & $\begin{array}{l}\text { Statistical process } \\
\text { control }\end{array}$ & $\begin{array}{l}\text { Aircraft model and } \\
\text { steel lighting device }\end{array}$ & $\begin{array}{l}\text { Subspace analysis of the Hankel } \\
\text { matrices is used for extracting } \\
\text { features. }\end{array}$ \\
\hline CSI/ref [97] & Modal parameters & - & $\begin{array}{l}\text { Z24 bridge benchmark } \\
\text { structure }\end{array}$ & $\begin{array}{l}\text { Stabilization diagram is adopted for } \\
\text { post processing of modal data. }\end{array}$ \\
\hline $\begin{array}{c}\text { McKelvey FD SSI } \\
{[98]}\end{array}$ & Modal parameters & - & $\begin{array}{l}\text { Uncontrolled } \\
\text { cantilever plate }\end{array}$ & $\begin{array}{l}\text { Natural frequency was predicted with } \\
\text { an average error of } 3.2 \% \text { and damping } \\
\text { ratio had an average error of } 2.8 \%\end{array}$ \\
\hline CC-SSI [100] & Modal parameters & - & Ariane 5 launch vehicle & $\begin{array}{l}\text { Clear results even in the case of } \\
\text { non-stationary data obtained using } \\
\text { this algorithm }\end{array}$ \\
\hline RSSI [101] & Modal parameters & - & $\begin{array}{l}\text { 3-story steel frame and } \\
\text { 2-story reinforced } \\
\text { concrete frame }\end{array}$ & $\begin{array}{l}\text { In this method the SVD algorithm is } \\
\text { replaced by an advanced algorithm to } \\
\text { update LQ decomposition. }\end{array}$ \\
\hline Improved SSI [102] & Modal parameters & - & $\begin{array}{l}\text { A numerical example } \\
\text { of } 7 \text { DOF and an } \\
\text { experimental model of } \\
\text { Chaotianmen bridge }\end{array}$ & $\begin{array}{l}\text { Less computing time due to not } \\
\text { having QR decomposition } \\
\mathrm{CH} \text { matrix is constructed as a } \\
\text { replacement for Hankel matrix. } \\
\text { Spurious modes are removed using } \\
\text { the model similarity index }\end{array}$ \\
\hline $\begin{array}{l}\text { ECCA-based SSI } \\
\text { algorithm [105] }\end{array}$ & Modal parameters & - & $\begin{array}{l}\text { FE model and } \\
\text { experimental wind } \\
\text { tunnel bridge model }\end{array}$ & $\begin{array}{l}\text { Enhanced results are achieved for } \\
\text { weakly excited modes and noisy } \\
\text { response signals }\end{array}$ \\
\hline
\end{tabular}

Covariance-Driven Stochastic Subspace Identification (SSI-COV) Method

SSI-COV is a parametric output-only method that is used for modal analysis. The method use the vibration response time-history to extract the state-space model of a dynamic system. SSI-COV is a two-step procedure that utilizes the correlation function of vibration time-history. The system order is the only user defined parameter in SSI and it must be carefully chosen to obtain meaningful results. In these methods, the applied excitation is considered as white noise and it is equal to the covariance of the measured response time-history.

Table 4 shows some SSI-COV algorithms that are applied for the damage detection of civil engineering structures. The damage indices in these methods are either modal parameters or a novel indicator for detecting changes that are caused by damage. In the previous two subsections, the application of SSI-DATA and SSI-COV algorithms for the damage detection of civil engineering structures was presented. In the following section, a comparison between the SSI algorithm and other key system identification methods in TD and FD is presented. 
Table 4. Some examples of the schemes that use covariance-driven subspace system identification (SSI-COV) in their damage identification process.

\begin{tabular}{|c|c|c|c|c|}
\hline Method/Reference & Damage Feature & $\begin{array}{c}\text { Pattern } \\
\text { Recognition }\end{array}$ & Test Model & Specification \\
\hline SSI-COV [106] & Subspace residual & Sensitivity analysis & Numerical analysis & $\begin{array}{l}\text { Damage localization using the FE } \\
\text { model }\end{array}$ \\
\hline $\begin{array}{l}\text { EMD-SSI-COV } \\
{[107]}\end{array}$ & $\begin{array}{l}\text { Intrinsic mode } \\
\text { functions }\end{array}$ & Sifting process & Beichuan arch bridge & $\begin{array}{l}\text { Capable of dealing with } \\
\text { non-stationary signals }\end{array}$ \\
\hline BSSI-COV [108] & $\begin{array}{c}\text { Curvature } \\
\text { evolution index }\end{array}$ & $\begin{array}{l}\text { Stabilization } \\
\text { diagram }\end{array}$ & $\begin{array}{l}\text { Numerical simulation of an } \\
\text { 7-DOF MSD model }\end{array}$ & $\begin{array}{l}\text { Suitable for identifying weakly } \\
\text { excited modes }\end{array}$ \\
\hline SSI-COV [109] & $\begin{array}{c}\text { Natural } \\
\text { frequencies }\end{array}$ & Fuzzy clustering & $\begin{array}{l}\text { Z24 Bridge and Republic } \\
\text { Plaza Office Tower }\end{array}$ & No need for mode shape data \\
\hline SSI-COV [110] & $\begin{array}{l}\text { Residual of the } \\
\text { observability } \\
\text { null-space }\end{array}$ & $\begin{array}{l}\text { Averaging } \\
\text { operation }\end{array}$ & $\begin{array}{l}\text { FE model of a bridge deck } \\
\text { and laboratory test of a } \\
\text { clamped beam within a } \\
\text { climatic chamber }\end{array}$ & $\begin{array}{l}\text { Temperature effect is evaluated } \\
\text { using an averaging operation }\end{array}$ \\
\hline SSI-COV [111] & Subspace residual & $\chi_{2}$ test & $\begin{array}{l}\text { Workbench and } \\
\text { instrumented beam }\end{array}$ & $\begin{array}{l}\text { Handling the temperature effect is } \\
\text { a target in this paper }\end{array}$ \\
\hline SSI-COV [112,113] & $\begin{array}{l}\text { State space } \\
\text { matrices }\end{array}$ & $\begin{array}{l}\text { Mahalanobis and } \\
\text { Euclidean distance } \\
\text { decision functions }\end{array}$ & $\begin{array}{l}\text { Two simulated beam model, } \\
\text { a laboratory-scale reinforced } \\
\text { concrete beam and a } \\
\text { full-scale arch bridge } \\
\text { structure }\end{array}$ & $\begin{array}{l}\text { The method was capable of } \\
\text { locating damage in beam } \\
\text { structures. }\end{array}$ \\
\hline $\begin{array}{l}\text { Recursive } \\
\text { SSI-COV-IV [114] }\end{array}$ & Modal parameters & - & $\begin{array}{l}\text { Numerical models of a } \\
\text { Single Degree of Freedom } \\
\text { (SDOF) structure and an } \\
\text { ASCE benchmark steel } \\
\text { frame structure }\end{array}$ & $\begin{array}{l}\text { Model identification was } \\
\text { conducted for a system with } \\
\text { time-varying measurement noise }\end{array}$ \\
\hline RD-SSIcov [115] & Modal parameters & $\begin{array}{l}\text { Modal strain } \\
\text { energy method }\end{array}$ & $\begin{array}{l}\text { Numerical model and a } \\
\text { small scale wind turbine } \\
\text { tower }\end{array}$ & $\begin{array}{l}\text { The RD method was selected in } \\
\text { this study for its noise reduction } \\
\text { capabilities. }\end{array}$ \\
\hline SSI-COV [116] & Modal parameters & $\begin{array}{l}\text { Local optimization } \\
\text { methods of NMA, } \\
\text { GA, HS and PSO }\end{array}$ & $\begin{array}{c}\text { Numerical examples and a } \\
\text { laboratory model of } \\
\text { cantilever beams }\end{array}$ & $\begin{array}{l}\text { The model is appropriate to } \\
\text { handle incomplete measurement } \\
\text { data and truncated mode shapes }\end{array}$ \\
\hline SSI-COV [117] & $\begin{array}{l}\text { Curvature change, } \\
\text { novelty index and } \\
\text { PCA-SSA (for } \\
\text { localization) modal } \\
\text { updating and } \\
\text { stiffness reduction } \\
\text { (for quantification) }\end{array}$ & Novelty analysis & $\begin{array}{l}\text { Laboratory-scale bridge } \\
\text { foundation scouring }\end{array}$ & $\begin{array}{l}\text { Detection, localization and } \\
\text { quantification was conducted in a } \\
\text { unified and online recursive } \\
\text { subspace algorithm }\end{array}$ \\
\hline SSI-COV [118] & $\begin{array}{l}\text { Eigenfrequencies, } \\
\text { damping ratios and } \\
\text { mode shapes }\end{array}$ & $\begin{array}{l}\text { Stabilization } \\
\text { diagram }\end{array}$ & $\begin{array}{l}\text { Experimental models of a } \\
\text { damaged pre-stressed } \\
\text { concrete bridge and a } \\
\text { mid-rise building }\end{array}$ & $\begin{array}{l}\text { Uncertainty quantification and } \\
\text { effect of different setups in modal } \\
\text { parameters was evaluated in this } \\
\text { study }\end{array}$ \\
\hline
\end{tabular}

\section{Comparison between SSI and Other System Identification Algorithms}

The SSI-DATA is a direct method and it does not need any data pre-processing to calculate correlation functions or spectrum analysis. On the other hand, the subspace identification algorithm uses QR factorization, SVD decomposition, and LS robust numerical techniques in the analysis process [119]. Several comparative studies are presented below in order to evaluate the advantages and drawbacks of the subspace identification algorithm when compared to other time and frequency domain damage identification methods in SHM. Table 5 presents a comparison between SSI method and other system identification algorithms. 
Table 5. Comparison between subspace system identification (SSI) method and other system identification algorithms.

\begin{tabular}{|c|c|c|}
\hline Reference & Identification Method & Advantages and Drawbacks \\
\hline Magalhães et al. [55] & $\begin{array}{l}\text { SSI } \\
\text { PP }\end{array}$ & $\begin{array}{l}\text { - Generally, there was a good agreement between the obtained modal frequencies and mode shape in all algorithms, however the } \\
\text { damping ratio shows the most significant scatter. } \\
\text { - The PP method is an appropriate technique for modal identification of closely spaced modes. } \\
\text { - SSI and FDD is a more appropriate choice for modal identification where closely spaced frequencies are not of the same type (e.g., } \\
\text { bending or torsion). } \\
\text { - PP and FDD are not suitable tools for identification of the modal parameters in cable-stayed bridges. Further analysis must be } \\
\text { undertaken to successfully discriminate the vibrational influence of the cables from the global bridge frequencies. } \\
\text { - The FDD and SSI yielded unreliable results for the second pair of closely spaced frequencies due to the coincidence of the modes and } \\
\text { coupling effect in ambient excitation. } \\
\text { - Estimation of damping ratios with wind-induced excitation has shown a significant level of scatter. Further research on ambient } \\
\text { vibration testing is needed to approach a reliable identification of damping coefficients. } \\
\text { - All the above-mentioned algorithms require human judgment during implementation. The user defined parameters for the SSI, FDD } \\
\text { and PP are system order, singular values, and global modes, respectively. }\end{array}$ \\
\hline Magalhães et al. [120] & $\begin{array}{l}\text { SSI-COV } \\
\text { p-LSCF } \\
\text { SSI }\end{array}$ & $\begin{array}{l}\text { - Performance of both SSI-COV and p-LSCF was found to be good in the identification of natural frequencies and mode shapes. } \\
\text { - It is demonstrated that p-LSCF can provide better estimation for the daily variations of damping coefficients compared to SSI. } \\
\text { - All of the modal identification methods perform well when the responses are exposed to noise. }\end{array}$ \\
\hline \multirow[t]{2}{*}{ Wang et al. [121] } & $\begin{array}{c}\text { ERA } \\
\text { ARMA }\end{array}$ & $\begin{array}{l}\text { - Model order is an important parameter in extracting correct modal parameters in all methods. } \\
\text { - Significant errors are observed in the damping coefficient when system order varies. } \\
\text { - Damping coefficient is sensitive to noise pollution, specifically for the first mode. }\end{array}$ \\
\hline & ITD & $\begin{array}{l}\text { - More stable results for modal identification were obtained by the SSI method in numerical simulations. However, the ERA method } \\
\text { outperforms other algorithms for field testing. } \\
\text { - ARMA shows the worst results for both field and numerical experiments. }\end{array}$ \\
\hline \multirow{6}{*}{ Moaveni et al. [122] } & MNExT-ERA & Comparing output-only methods of SSI-DATA, MNExT-ERA and EFDD, it can be inferred that: \\
\hline & SSI-DATA & $\begin{array}{l}\text { - The identified natural frequencies using these methods display good agreement in each damage scenario. } \\
\text { - The identified damping coefficient shows larger variability but still in a reasonable range. }\end{array}$ \\
\hline & EFDD & $\begin{array}{l}\text { - Lower damping ratios are obtained through FDD than the results identified using SSI-DATA and MNExT-ERA. } \\
\text { - The identified mode shapes using SSI-DATA were confirmed to be the most reliable among all methods. }\end{array}$ \\
\hline & DSI & Comparing input-output methods of DSI, OKID-ERA, and GRA, the following were observed: \\
\hline & OKID-ERA & - The identified mode-shapes in all of the above-mentioned algorithms are close to the actual mode shape of the structure. \\
\hline & GRA & $\begin{array}{l}\text { - In general, the calculated mode shapes by the input-output methods are more accurate than those obtained from output-only methods. } \\
\text { - The mode-shape parameters obtained from the GRA appear to be in good agreement with the actual mode shapes of the structure. }\end{array}$ \\
\hline Cunha et al. [123] & $\begin{array}{l}\text { SSI-COV } \\
\text { FDD }\end{array}$ & $\begin{array}{l}\text { - The same result in terms of damage detection was obtained using both the SSI-COV and FDD procedures. } \\
\text { - In terms of modal parameters, perfect results were extracted through using both methods. }\end{array}$ \\
\hline
\end{tabular}


Table 5. Cont.

\begin{tabular}{|c|c|c|}
\hline Reference & Identification Method & Advantages and Drawbacks \\
\hline \multirow{6}{*}{ Liu et al. [54] } & SSI and ERA & $\begin{array}{l}\text { - Both the ERA and SSI methods are accurate and provide stable results for modal parameters. The methods are extremely sensitive to } \\
\text { the size of the Hankel matrix. } \\
\text { - The work burden of the algorithms is large and usually needs to perform multiple analyses. }\end{array}$ \\
\hline & PolyMAX & $\begin{array}{l}\text { - The PolyMAX and PolyLSCF methods are fast but the operator needs to have a high qualification. } \\
\text { - The algorithm is sensitive to the size of the Hankel matrix and sometimes needs to perform multiple analyses. }\end{array}$ \\
\hline & PPM & $\begin{array}{l}\text { - PPM is a simple and less demanding algorithm. } \\
\text { - The algorithm can identify modal parameters in the pre-defined frequency range. }\end{array}$ \\
\hline & PZM & $\begin{array}{l}\text { - PZM and PolyLSCF are basically similar and the obtained results can complement each other. } \\
\text { - EZM uses a non-power spectrum for modal frequencies and damping. }\end{array}$ \\
\hline & EFDD and FSDD & $\begin{array}{l}\text { - The estimation precisions in these methods depend on the accuracy of the power spectral density. } \\
\text { - Both methods are sensitive to noise and leakage error. }\end{array}$ \\
\hline & WT & - The accuracy of the WT is relatively high. \\
\hline \multirow{3}{*}{ Kim and Lynch [53] } & SSI & $\begin{array}{l}\text { - The WT is not conducive to the real-time monitoring due to analysis loa } \\
\text { - Similar performance was confirmed for the SSI and FDD methods. }\end{array}$ \\
\hline & FDD & - The FDD method slightly suffered from resolution problems due to the limited number of data points. \\
\hline & & - Though SSI has no resolution problems, more scattered data are generated when dealing with output-only mod \\
\hline \multirow{3}{*}{$\begin{array}{l}\text { Ceravolo and Abbiati } \\
{[124]}\end{array}$} & $\begin{array}{l}\text { SSI-DATA } \\
\text { AR }\end{array}$ & $\begin{array}{l}\text { - All three output-only methods of SSI-DATA, AR and ERA/RDS show high robustness to modal frequency estimation in non-stationary } \\
\text { conditions. }\end{array}$ \\
\hline & & - By using the same methods, damping estimates were very scattered. \\
\hline & ERA/RDS & $\begin{array}{l}\text { - The estimation error of modal frequency in all methods remained less than } 1.5 \% \text {. } \\
\text { - The error in estimating damping ratio ranged from } 15 \% \text { (in SSI) to } 50 \% \text { (in AR). }\end{array}$ \\
\hline
\end{tabular}


Table 5 shows the results of a comparison between several TD, FD, and time-frequency domain methods for damage detection and modal analysis of civil engineering structures. The obtained results confirm the reliable performance of the TD methods. It was shown that SSI is a powerful tool for modal identification, in which closely spaced frequencies are not of the same type (e.g., bending or torsion) [55]. It was reported that the identified mode shapes using SSI-DATA were the most reliable when compared to MNExT-ERA or EFDD [122]. Moreover, fewer errors were obtained in estimating the damping ratio using the SSI algorithm as compared to ARMA [124]. However, SSI has some disadvantages, such as requiring human judgment of system order for implementation [55]. On the other hand, the work burden of the SSI algorithm is large and it usually needs to perform multiple analyses [54].

\section{Challenges of SSI in Practical Application}

Research on the application of subspace methods for the damage detection of civil structures emerged in the mid-1990s. Most of the methods used in SHM presume a parametric model of a dynamic system in order to characterize structural behavior under an applied excitation load. However, civil engineering structures still have many challenges to achieve a robust SHM model. The size of civil structures does not permit a large number of sensors to be mounted on a structure. Moreover, forced-vibration is not considered to be practical due to interruption in the serviceability of structures. On the other hand, civil structures are complex in terms of geometry and their material properties involve a large range of uncertainty due to operational and environmental factors [125]. In Table 6, the problems that are faced with practical implementation of SHM systems using the SSI algorithm and the researches to resolve the associated problems are presented.

Table 6 reviews the challenges of implementing the subspace algorithm in real-world applications. In practical applications of SHM, the response signal of structures is generally in the form of a non-Gaussian random signal. In such conditions, deterministic techniques result in unreliable system models. On the other hand, data loss or corruption caused by failure or loss of sensing, transmission, or storage devices during their normal use is a concern for a reliable damage detection scheme. Consequently, appropriate procedures must be considered in order to deal with the uncertainty that is caused by such instrumental failures. The accuracy of an identification algorithm is due not only to its insensitivity to environmental variation and instrumental failure, but also to the inherent performance of the estimation scheme. Studies have been conducted to improve the performance of the SSI method and enhance the modal identification process itself. The inherent performance of an estimation scheme to deal with problems, such as the short-length of a signal, non-stationarity measurement data, system non-linearity, leakage error, or different measurement setups remains a challenge for a reliable SHM. In some cases, resolving the problem and increasing the accuracy demands exhaustive expert assistance and time-consuming computation burdens. Gluing the non-simultaneously measured set-ups of sensor data is another controversial issue that needs to be considered before applying any identification platform. The aforementioned drawbacks are the topic of ongoing research in the field of SHM. 
Table 6. The challenges of SSI in practical applications.

\begin{tabular}{|c|c|c|}
\hline Reference & Method & Concern \\
\hline Peeters and De Roeck [126] & SSI & $\begin{array}{c}\begin{array}{c}\text { Dealing with the sensor data of different measurement } \\
\text { setups. }\end{array}\end{array}$ \\
\hline Pridham and Wilson [127] & $\begin{array}{l}\text { Correlation-driven subspace } \\
\text { algorithm }\end{array}$ & $\begin{array}{l}\text { The effect of sample size and the dimension of the Hankel } \\
\text { matrix on the estimated damping coefficient }\end{array}$ \\
\hline Pan [128] & - & Discriminates the effects of epistemic uncertainty \\
\hline Benveniste and Mevel [129] & SSI & $\begin{array}{l}\text { Consistency of the subspace algorithm against } \\
\text { non-stationarities in the measurement data }\end{array}$ \\
\hline Reynders et al. [130] & SSI & Removing bias errors in ambient vibrations \\
\hline Brasiliano et al. [131] & SSI-COV and SSI-DATA & $\begin{array}{l}\text { Effect of non-structural elements in the vibrational behavior } \\
\text { of bridge structures. }\end{array}$ \\
\hline Alıcıoğlu \& Luş [132] & $\begin{array}{c}\text { SSI-COV and SSI-DATA } \\
\text { techniques through BR and CVA. }\end{array}$ & $\begin{array}{c}\text { The effect of structural complexity and ambient conditions } \\
\text { on modal identification. }\end{array}$ \\
\hline Marchesiello et al. [133] & ST-SSI & Time-variant identification \\
\hline Balmès et al. [134] & Extended SSI-COV-based & $\begin{array}{l}\text { Handling temperature effect in the identified modal } \\
\text { parameters. }\end{array}$ \\
\hline Wang et al. [135] & SSI together with ARX & $\begin{array}{l}\text { Damage detection of Hammerstein systems or non-linearity } \\
\text { introduced to a linear dynamic system through piece-wise } \\
\text { constant inputs }\end{array}$ \\
\hline Magalhães et al. [136] & EFDD and SSI-COV & $\begin{array}{l}\text { Quality of the extracted damping ratios considering the } \\
\text { proximity of natural frequencies, non-proportional damping } \\
\text { and accuracy of the identification algorithms }\end{array}$ \\
\hline Döhler et al. [137] & SSI-COV & Multiple non-simultaneously recorded measurement setups. \\
\hline Carden and Mita [138] & $\begin{array}{l}\text { A combined SSI-DATA method } \\
\text { and first order perturbation } \\
\text { technique }\end{array}$ & $\begin{array}{l}\text { The challenges faced in extracting the accurate confidence } \\
\text { interval of modal parameters in civil engineering structures. }\end{array}$ \\
\hline Döhler and Mevel [139] & $\begin{array}{l}\text { SSI- a modular and scalable } \\
\text { approach }\end{array}$ & Merging sensor data by applying a modular approach. \\
\hline Döhler et al. [140] & $\begin{array}{l}\text { First-order SSI method } \\
\text { perturbation analysis }\end{array}$ & $\begin{array}{c}\text { Evaluation of the statistical uncertainty in a multi-setup } \\
\text { configuration }\end{array}$ \\
\hline Loh and Chen [141] & $\begin{array}{l}\text { Hybrid RSSI-COV, NLPCA and } \\
\text { AANN }\end{array}$ & $\begin{array}{l}\text { Distinguishing the damage abnormality from those caused } \\
\text { by environmental and operational variations }\end{array}$ \\
\hline Brehm et al. [142] & $\begin{array}{l}\text { Power spectral amplitudes and FE } \\
\text { model }\end{array}$ & $\begin{array}{c}\begin{array}{c}\text { Determination of the optimum position of the reference } \\
\text { sensor }\end{array}\end{array}$ \\
\hline Cara et al. [143] & $\begin{array}{l}\text { Kalman filter } \\
\text { SSI algorithm }\end{array}$ & $\begin{array}{l}\text { Contribution of the modal parameters in each mode to the } \\
\text { recorded measurement data. }\end{array}$ \\
\hline Ashari and Mevel [144] & SSI-based algorithm & Injecting auxiliary input to extract the unexcited modes \\
\hline Tondreau and Deraemaeker, [145] & Monte-Carlo and SSI & Introducing uncertainty into an FE model \\
\hline Rainieri and Fabbrocino [146] & SSI & $\begin{array}{c}\text { Influence of the system order and number of block rows in } \\
\text { identification accuracy }\end{array}$ \\
\hline Cho et al. [147] & SDSI & Implementation of VDD using wireless sensor networks \\
\hline Markovsky [148] & SSI & Influence of missing measurement data in dynamic system \\
\hline Banfi \& Carassale [149] & SSI, SRA and FDD & Effect of uncertainty in determining modal parameters \\
\hline Spiridonakos et al. [150] & PCE & Humidity and temperature effects \\
\hline Huynh et al. [151] & $\begin{array}{l}\text { A combined SSI algorithm and } \\
\text { short-time Fourier transform }\end{array}$ & $\begin{array}{c}\text { Structural analysis of a cable-stayed bridge under typhoons } \\
\text { with various wind speeds. }\end{array}$ \\
\hline Ren et al. [152] & Improved SSI algorithm & Eliminating spurious modes caused by non-white noise \\
\hline
\end{tabular}




\section{Application of Subspace Identification in Civil Engineering Structures}

Currently, stochastic subspace methods are widely accepted tools in civil engineering communities. Large number of SHM methods is operating in structures that are subjected to dynamic vehicular, seismic, wind, or impact loading. In this study, the application of the SSI algorithm in civil engineering structures is investigated in the following three categories:

1. beams and two dimensional (2D) frames;

2. three dimensional (3D) frames and building structures; and,

3. bridges and other structures.

Beams and two-dimensional (2D) models attempt to explain the performance of the SHM algorithm while using numerical FE or laboratory-scale models [153]. Many of the studies on these structures are generally academic in nature. Three-dimensional (3D) frames and building structures are generally used to investigate the practical aspects of SHM. Bridges are spectacular due to their specific loading conditions when compared to building-type structures [154]. Vehicular and pedestrian loading, together with exposure to environmental variations due to temperature and wind precipitation, have been the focus of the analysis of bridge structures in many pioneering studies of SHM [155]. Tables 7-9 show some application of SSI algorithms for damage detection of 2D frames, 3D frames, and buildings and bridges, and other structures, respectively.

Table 7. Application of SSI algorithms for damage detection of beams and two-dimensional (2D) frames.

\begin{tabular}{|c|c|c|c|c|}
\hline Reference & $\begin{array}{c}\text { Applied Damage } \\
\text { Detection Technique }\end{array}$ & Test Structure & Damage Configuration & $\begin{array}{c}\text { Damage Identification } \\
\text { Results }\end{array}$ \\
\hline $\begin{array}{l}\text { Vanlanduit et al. } \\
\text { [156] }\end{array}$ & $\begin{array}{c}\text { Subspace theory and } \\
\text { RSVD }\end{array}$ & $\begin{array}{l}\text { Laboratory-scale } \\
\text { aluminum beam }\end{array}$ & $\begin{array}{l}\text { (1) } 30 \% \text { and } 50 \% \text { sew cut in the } \\
\text { middle } \\
\text { (2) A beam with fatigue crack } \\
\text { under several geometrical and } \\
\text { damping conditions. }\end{array}$ & $\begin{array}{l}\text { Reliable results were obtained } \\
\text { by applying the introduced } \\
\text { RSVD method. }\end{array}$ \\
\hline $\begin{array}{l}\text { Naseralavi et al. } \\
\text { [157] }\end{array}$ & $\begin{array}{c}\text { Theory of subspaces } \\
\text { and Kernel } \\
\text { parallelization }\end{array}$ & $\begin{array}{c}\text { Three simulations } \\
\text { of } 1 \mathrm{D} \text { and } 2 \mathrm{D} \text { case } \\
\text { studies }\end{array}$ & $\begin{array}{l}\text { Reduction in Young's } \\
\text { modulus ranging from } 10 \% \text { to } \\
30 \% \text { correlated with the extent } \\
\text { of the damage }\end{array}$ & $\begin{array}{l}\text { Most single and multiple } \\
\text { damage scenarios }\end{array}$ \\
\hline $\begin{array}{l}\text { Döhler and Hille } \\
\text { [158] }\end{array}$ & Subspace-based & $\begin{array}{l}\text { (1) Numerical } \\
\text { simulations } \\
\text { (2) A 1D steel } \\
\text { frame structure }\end{array}$ & $\begin{array}{l}\text { The crack-like damage } \\
\text { simulated by the loosened } 3 \text { to } \\
7 \text { number of bolts, which } \\
\text { correlates with a reduction of } \\
\text { bending stiffness from } 3 \% \text { to } \\
30 \% \text {, respectively. }\end{array}$ & $\begin{array}{l}\text { All damage cases were clearly } \\
\text { detected under variable } \\
\text { excitation using the new test } \\
\text { method }\end{array}$ \\
\hline
\end{tabular}


Table 8. Application of SSI algorithms for damage detection of three-dimensional (3D) frames and buildings.

\begin{tabular}{|c|c|c|c|c|}
\hline Reference & $\begin{array}{c}\text { Applied Damage } \\
\text { Detection Technique }\end{array}$ & Test Structure & Damage Configuration & $\begin{array}{c}\text { Damage Identification } \\
\text { Results }\end{array}$ \\
\hline Siegert et al. [160] & $\begin{array}{c}\text { Statistical } \\
\text { subspace-based } \\
\text { algorithm }\end{array}$ & $\begin{array}{c}\text { Laboratory-scale composite } \\
\text { bridge deck }\end{array}$ & $\begin{array}{l}40 \% \text { reduction of the } \\
\text { Young modulus }\end{array}$ & $\begin{array}{l}\text { Algorithm can successfully } \\
\text { detect the damages of the } \\
\text { structure investigated }\end{array}$ \\
\hline Li and Chang [114] & SSI and IV & $\begin{array}{l}\text { Numerical model of a } \\
\text { four-story, ASCE benchmark } \\
\text { steel frame }\end{array}$ & $\begin{array}{l}\text { A damage case of } 30 \% \\
\text { reduction in the stiffness of } \\
\text { the first story }\end{array}$ & $\begin{array}{l}\text { Application of the } \\
\text { technique tracking } \\
\text { damages in the presence of } \\
\text { measurement noise was } \\
\text { successful. }\end{array}$ \\
\hline Huang et al. [161] & SSI and DLV & $\begin{array}{l}\text { Numerical model and } \\
\text { laboratory-scale of a } \\
\text { five-story steel frame }\end{array}$ & $\begin{array}{l}\text { Damage scenarios with } \\
\text { single and two damage } \\
\text { case inflicted on the first } \\
\text { second, third and fourth } \\
\text { stories' columns }\end{array}$ & $\begin{array}{l}\text { (1) Poor results were } \\
\text { recorded for multiple } \\
\text { damage cases. } \\
\text { (2) The obtained result for } \\
\text { the ill-conditioned } \\
\text { counterpart was effective. }\end{array}$ \\
\hline Wang et al. [163] & SSI and DLV & $\begin{array}{l}\text { Five-story shear frame } \\
\text { structure with diagonal } \\
\text { bracings. }\end{array}$ & $\begin{array}{l}\text { Damage conditions } \\
\text { simulated by partially } \\
\text { removing some of the } \\
\text { bracings }\end{array}$ & $\begin{array}{l}\text { The proposed algorithm } \\
\text { for damage localization } \\
\text { was successful }\end{array}$ \\
\hline $\begin{array}{l}\text { Moaveni et al. } \\
\text { [164] }\end{array}$ & $\begin{array}{l}\text { Deterministic-stochastic } \\
\text { subspace identification }\end{array}$ & $\begin{array}{l}\text { Laboratory-scale, three-story, } \\
\text { two-bay, infilled RC }\end{array}$ & $\begin{array}{c}\text { Progressive damage } \\
\text { induced by shaking table } \\
\text { experiencing scaled } \\
\text { earthquake records. }\end{array}$ & $\begin{array}{l}\text { Natural frequencies } \\
\text { decrease with increase in } \\
\text { damage level during the } \\
\text { test experiment }\end{array}$ \\
\hline $\begin{array}{c}\text { Karami and } \\
\text { Akbarabadi [166] }\end{array}$ & $\begin{array}{l}\text { Active control strategy } \\
\text { and SSI }\end{array}$ & $\begin{array}{l}\text { Numerical model of a } 5 \text { story } \\
\text { and a } 20 \text { story shear building }\end{array}$ & $\begin{array}{l}\text { Reduction in the stories' } \\
\text { lateral stiffness ranged } \\
\text { from } 10 \text { to } 50 \%\end{array}$ & $\begin{array}{l}\text { The algorithm can detect } \\
\text { damages accurately. }\end{array}$ \\
\hline Belleri et al. [167] & $\begin{array}{l}\text { Combined } \\
\text { deterministic-stochastic } \\
\text { subspace identification }\end{array}$ & $\begin{array}{l}\text { Real-size three-story } \\
\text { half-scale precast concrete } \\
\text { building }\end{array}$ & $\begin{array}{l}\text { Base excitation leading to } \\
\text { loss of stiffness, cracks, and } \\
\text { failure of the connections }\end{array}$ & $\begin{array}{l}\text { Damage reduces natural } \\
\text { frequencies and increases } \\
\text { the damping ratios }\end{array}$ \\
\hline $\begin{array}{l}\text { Shinagawa and } \\
\text { Mita [168] }\end{array}$ & Subspace identification & $\begin{array}{l}\text { Full-scale four-story steel } \\
\text { building }\end{array}$ & Collapse test. & $\begin{array}{l}\text { Strong correlation between } \\
\text { the extracted features with } \\
\text { structural damage was } \\
\text { observed. }\end{array}$ \\
\hline Zhou et al. [169] & $\begin{array}{l}\text { Subspace-based } \\
\text { methods }\end{array}$ & $\begin{array}{l}\text { A six-story residential } \\
\text { building }\end{array}$ & $\begin{array}{l}\text { More than } 20 \text { earthquake } \\
\text { aftershocks recorded after } \\
\text { instrumentation }\end{array}$ & $\begin{array}{l}\text { Results of damage } \\
\text { detection were not very } \\
\text { reliable for earthquake } \\
\text { induced excitation }\end{array}$ \\
\hline $\begin{array}{l}\text { Yoshimoto et al. } \\
\text { [170] }\end{array}$ & $\begin{array}{l}\text { MIMO SSI method and } \\
\text { sub-structuring }\end{array}$ & $\begin{array}{l}\text { An existing 7-story } \\
\text { base-isolated building. }\end{array}$ & $\begin{array}{l}\text { Stiffness reduction in the } \\
\text { stories }\end{array}$ & $\begin{array}{l}\text { The estimated damage of } \\
\text { the stories correlates with } \\
\text { the reduction ratio. }\end{array}$ \\
\hline
\end{tabular}


Table 9. Application of SSI algorithms for damage detection of bridges and other structures.

\begin{tabular}{|c|c|c|c|c|}
\hline Reference & $\begin{array}{c}\text { Applied Damage } \\
\text { Detection Technique }\end{array}$ & Test Structure & Damage Configuration & $\begin{array}{c}\text { Damage Identification } \\
\text { Results }\end{array}$ \\
\hline $\begin{array}{l}\text { Allahdadian et al. } \\
\text { [171] }\end{array}$ & SSDD and $\chi^{2}$ test & Reibersdorf Bridge & $\begin{array}{l}\text { Damage simulated in } \\
\text { girder, column, bearing, } \\
\text { deck and cap beam with } \\
\text { the ratios varied between } \\
20 \%, 40 \% \text { and } 80 \% .\end{array}$ & $\begin{array}{l}\text { Unable to detect minor } \\
\text { damage with a ratio of } 20 \%\end{array}$ \\
\hline $\begin{array}{l}\text { Deraemaeker et al. } \\
\text { [173] }\end{array}$ & $\begin{array}{c}\text { Automated SSI and } \\
\text { Shewhart-T control } \\
\text { charts }\end{array}$ & $\begin{array}{l}\text { Numerical model of a } 3 \text { span } \\
\text { bridge }\end{array}$ & $\begin{array}{l}\text { Four damage scenarios } \\
\text { simulated by stiffness } \\
\text { reduction in three different } \\
\text { locations. }\end{array}$ & $\begin{array}{l}\text { Proposed method was } \\
\text { capable of detecting } \\
\text { damage scenarios }\end{array}$ \\
\hline Loh and Chao [175] & SSI-COV and MSSA & Laboratory-scale bridge & $\begin{array}{l}\text { Displacement and } \\
\text { lowering of a pier due to } \\
\text { scouring }\end{array}$ & $\begin{array}{l}\text { Localization and } \\
\text { quantification were } \\
\text { successful }\end{array}$ \\
\hline $\begin{array}{l}\text { Mevel and Goursat } \\
\text { [176] }\end{array}$ & SSI & Z24 Bridge & $\begin{array}{l}\text { Pier settlement of } 20 \mathrm{~mm} \\
\text { and } 80 \mathrm{~mm} .\end{array}$ & $\begin{array}{l}\text { The efficiency of the } \\
\text { proposed method was } \\
\text { confirmed }\end{array}$ \\
\hline Lin et al. [113] & Statistics-based SSI & $\begin{array}{l}\text { (1) Laboratory-sale } \\
\text { pre-stressed RC beams } \\
\text { (2) a full-scale RC arch } \\
\text { bridge }\end{array}$ & $\begin{array}{l}\text { Gradually releasing the } \\
\text { pre-stressed tendon from } \\
17 \% \text { to } 73 \%\end{array}$ & $\begin{array}{l}\text { Algorithm was successful } \\
\text { in detecting damage }\end{array}$ \\
\hline $\begin{array}{l}\text { Reynders, and De } \\
\text { Roeck [178] }\end{array}$ & $\begin{array}{l}\text { SSI algorithm and } \\
\text { KPCA }\end{array}$ & $\mathrm{Z} 24$ & $\begin{array}{l}\text { Pier settlement, tilt of } \\
\text { foundation, concrete } \\
\text { spalling, landslide of } \\
\text { abutment, failure of } \\
\text { concrete hinge, failure of } \\
\text { anchor heads and rupture } \\
\text { of tendons were } \\
\text { introduced to the structure }\end{array}$ & $\begin{array}{l}\text { The proposed algorithm } \\
\text { was capable of detecting } \\
\text { imperfection in most cases }\end{array}$ \\
\hline Nguyen et al. [179] & NSA and EPCA & $\begin{array}{l}\text { Numerical model of } \\
\text { Champangshiehl Bridge }\end{array}$ & $\begin{array}{l}\text { Several intentionally } \\
\text { created cuttings in } \\
\text { pre-stressed tendons }\end{array}$ & $\begin{array}{l}\text { The obtained result was } \\
\text { encouraging. }\end{array}$ \\
\hline
\end{tabular}

In most structures, damage occurs in the form of a reduction in the cross-section of structural members. Partial reductions in 2D structures are usually detectable with a high level of precision. The robust applicability of the proposed methods to solve the problem of detecting local damage in real and complicated civil engineering structures has not been validated, even though these methods work relatively well in simple structures. Three-dimensional frames and building structures are generally complex and they pose challenges for both practitioners and researchers. Damage in building structures is usually in the form of a partial reduction in the cross-sectional area in column elements. In some cases, damage is made by opening bolts in a beam-column connection. However, beam damages are less important and they require higher detectability resolution. Bridge structures are a very important element of transportation. An in-service bridge is subject to loads, such as traffic, temperature variation, wind loading, and deterioration, under aggressive environments. Applying SHM to bridge structures poses significant challenges due to the specific types of loading and complexity of the structure. As a general conclusion, it could be derived that damage detection strategies that use modal frequencies, mode shapes or mode shape curvatures as their damage sensitive features [180] are only efficient for 
the detection of global damage and are not generally sensitive enough to detect changes in the local elements of structures [181].

\section{Application of Subspace Identification in Civil Engineering Structures}

In general, an individual program or a combination of software packages implement the process of damage detection [182,183]. A structural monitoring program is considered an algorithm for analyzing response signals, extracting damage features and deploying pattern recognition paradigms, ultimately leading to damage identification [184]. Subspace methods have been used as the central part of many of the structural monitoring programs used in industry $[185,186]$. In this subsection, the industrial software packages used in modal identification and SHM, which have adapted SSI as their core identification process, are further investigated.

Table 10 provides some of the commercially available software that use subspace identification algorithms as their standard technique for SHM and modal analysis. Most of the available algorithms are generally used for modal analysis. The SHM algorithms are composed of (i) identification, (ii) feature extraction, and (iii) pattern recognition steps and the implementation of a unified algorithm for huge diversity of each category is quite challenging and rewarding.

Table 10. SSI-based commercially available software for SHM and modal analysis.

\begin{tabular}{ccccc}
\hline Reference & Software & Analysis Tool & Environment & Purpose \\
\hline Döhler et al. [182] & ARTeMIS & CC-SSI & - & Modal identification \\
Y. Zhou et al. [183] & ModalVIEW & SSI, RPF and LSCF & LabVIEW & Modal identification \\
Hu et al. [184] & SMI & EFDD & LabVIEW & Modal identification \\
Hu et al. [184] & CSMI & PP, FDD and SSI & LabVIEW & Modal identification \\
Goursat \& Mevel [186] & COSMAD & SSI-COV & Scilab & Modal identification \\
Chang et al. [185] & SMIT & $\begin{array}{c}\text { SSI, auto-regressive-based } \\
\text { methods and }\end{array}$ & MATLAB & SHM \\
& & realization-based algorithms & & \\
\hline
\end{tabular}

\section{Future Research Directions}

In the future, researchers should focus on the identification of local damages by improving the accuracy and noise-robustness of damage identification algorithms $[187,188]$. Furthermore, they must think about introducing a novel platform for the implementation of commercialized SHM software that is versatile enough to deal with the diversity of techniques in a damage detection system. Providing a user-friendly platform for the implementation of the SHM algorithm will improve the general usage of SHM software in solving real-life engineering problems. Furthermore, the extensible architecture would enhance the applicability of the software by enabling users to modify the existing base code and add their own extensions. A modular and flexible architecture enables a wide variety of reported methods to deal with within an integrated framework. Enhancing the SSI properties to deal with real-world applications, such as noise inclusion, short length data, and gluing sensor data, will enhance accuracy to provide more reliable damage detection results.

\section{Conclusions}

This paper presented a review of the recent advances in subspace-based SHM methods. SSI is a powerful choice for modal identification, particularly when dealing with closely spaced frequencies or noisy response signals. The identified mode shapes using SSI-DATA were confirmed to be the most reliable when compared to MNExT-ERA and EFDD. Moreover, fewer errors were obtained in estimating the damping ratio using the SSI algorithm as compared to ARMA. However, there are some disadvantages in using SSI, such as requiring human judgment for system order and large work burden of the SSI algorithm. 
In most structures, damage is imposed in the form of a reduction in the cross-section of structural members. A review on applied models used for verification of damage detection algorithms shows that damages in the 2D structures are usually detectable with a high level of precision. Three-dimensional frames and building structures are generally complex and pose challenges for both practitioners and researchers. Even though lots of proposed SHM algorithms work relatively well in simple structures, the robust application of these methods to solve the problem of local damage detection in real and complicated civil engineering structures has not been validated. The obtained results demonstrate that damage detection strategies that use vibration parameters of a dynamic system are only efficient for the detection of global damages and they are not generally sensitive enough to detect local damages in structures.

Most commercially available software is generally designed for modal analysis and cannot be directly used for the SHM of structures. The commercial modal analysis toolboxes introduced are mainly implemented while using LabVIEW, which adapts a limited number of system identification methods, for example, SSI, LSCF, FDD, and SSI. The identification of modal parameters generally starts with extracting the response signal of structures and it results in the modal parameters of natural frequency, mode shapes, and damping ratio. However, SHM algorithms are generally complicated due to the wide variety of methods reported and their inherent structures. Hence, the implementation for the large diversity found in each category within a unified algorithm is quite a challenging problem.

Author Contributions: Resources, H.S. (Hoofar Shokravi), H.S. (Hooman Shokravi), N.B., S.S.R.K. and M.P.; investigation, H.S. (Hoofar Shokravi); writing-original draft preparation, H.S. (Hoofar Shokravi) and H.S. (Hooman Shokravi); writing-review and editing, H.S. (Hoofar Shokravi), H.S. (Hooman Shokravi), N.B. and S.S.R.K.; visualization, H.S. (Hoofar Shokravi), H.S. (Hooman Shokravi), N.B., S.S.R.K. and M.P.; supervision, N.B.; project administration, H.S. (Hoofar Shokravi), H.S. (Hooman Shokravi), N.B., S.S.R.K. and M.P.; funding acquisition, N.B., S.S.R.K. and M.P.; All authors have read and agreed to the published version of the manuscript.

Funding: This research was funded by Ministry of Higher Education, Malaysia, and Universiti Teknologi Malaysia (UTM) for their financial support through the Fundamental Research Grant Scheme (grant number: 4F800) and Higher Institution Centre of Excellent grant (grant number: 4J224) The APC was funded by Ministry of Education, Youth, and Sports of the Czech Republic and the European Union (European Structural and Investment Funds Operational Program Research, Development, and Education) in the framework of the project "Modular platform for autonomous chassis of specialized electric vehicles for freight and equipment transportation", Reg. No. CZ.02.1.01/0.0/0.0/16_025/0007293.

Acknowledgments: The authors would like to thank the Ministry of Higher Education, Malaysia, and Universiti Teknologi Malaysia (UTM) for their financial support through the Fundamental Research Grant Scheme (4F800) and Higher Institution Centre of Excellent grant (4J224), Ministry of Education, Youth, and Sports of the Czech Republic and the European Union (European Structural and Investment Funds Operational Program Research, Development, and Education) in the framework of the project "Modular platform for autonomous chassis of specialized electric vehicles for freight and equipment transportation", Reg. No. CZ.02.1.01/0.0/0.0/16_025/0007293.

Conflicts of Interest: The authors declare no conflict of interest.

\section{Nomenclature}

$\begin{array}{ll}\text { AR } & \text { Auto regressive } \\ \text { ARMA } & \text { Auto-regressive moving average } \\ \text { ARMAX } & \text { Auto-Regressive Moving Average with eXogenous variable } \\ \text { ARX } & \text { Auto-Regressiv with eXogenous input } \\ \text { BFD } & \text { Basic frequency-domain } \\ \text { CE } & \text { Complex exponential } \\ \text { CMIF } & \text { Complex mode indication function } \\ \text { CVA } & \text { Canonical variate analysis } \\ \text { EFDD } & \text { Enhanced frequency domain decomposition } \\ \text { eFRF } & \text { Enhanced frequency response function } \\ \text { ERA } & \text { Eigensystem realization algorithm } \\ \text { ERA/DC. } & \text { ERA using data correlations } \\ \text { ERA-OKID-OO } & \text { Output-only ERA-OKID }\end{array}$




\begin{tabular}{|c|c|}
\hline ET & Eddy current test \\
\hline EVD & Eigen-vector decomposition \\
\hline FD & Frequency-domain \\
\hline FE & Finite element \\
\hline FFT & Fast Fourier transforms \\
\hline FRF & Frequency response functions \\
\hline IPCE & Improved polyreference complex exponential \\
\hline ITD & Ibrahim time-domain \\
\hline LS & Least-squares \\
\hline LSCE & Least-squares complex exponential \\
\hline MA & Moving average \\
\hline MIMO & Multiple-input multiple-output \\
\hline MOESP & Multivariable output error state-space \\
\hline MRITD & Multiple references Ibrahim time-domain \\
\hline N4SID & Numerical algorithms for state-space subspace system identification \\
\hline NDE & Non-destructive evaluation \\
\hline NExT & Natural excitation technique \\
\hline O3KID & Output-only observer/Kalman filter identification \\
\hline OKID & Observer/Kalman filter identification \\
\hline PAUT & Phased array ultrasonic test \\
\hline pLSCF & Poly-reference least squares complex frequency-domain \\
\hline PolyMAX & Polyreference least-squares complex frequency-domain method \\
\hline $\mathrm{PP}$ & Peak picking \\
\hline PRCE & Polyreference complex exponential \\
\hline $\mathrm{RD}$ & Random decrement \\
\hline RDS & Random decrement signatures \\
\hline RT & Radiographic test \\
\hline SDD & Static-based damage detection \\
\hline SHM & Structural health monitoring \\
\hline SIMO & Single-input multiple-output \\
\hline SISO & Single-input single-output \\
\hline SSI & Subspace system identification \\
\hline SSI-COV & Covariance-driven subspace system identification \\
\hline SSI-DATA & Data-driven subspace system identification \\
\hline SVD & Singular value decomposition \\
\hline TARMA & Time-dependent auto-regressive moving average \\
\hline TD & Time-domain \\
\hline TFD & Time/frequency domain \\
\hline $\mathrm{UT}$ & Ultrasonic test \\
\hline VDD & Vibration-based damage detection \\
\hline
\end{tabular}

\section{References}

1. Zhao, H.; Ding, Y.; Nagarajaiah, S.; Li, A. Longitudinal Displacement Behavior and Girder End Reliability of a Jointless Steel-Truss Arch Railway Bridge during Operation. Appl. Sci. 2019, 9, 2222. [CrossRef]

2. Artese, S.; Nico, G. TLS and GB-RAR Measurements of Vibration Frequencies and Oscillation Amplitudes of Tall Structures: An Application to Wind Towers. Appl. Sci. 2020, 10, 2237. [CrossRef]

3. Zhou, L.; Guo, J.; Wen, X.; Ma, J.; Yang, F.; Wang, C.; Zhang, D. Monitoring and Analysis of Dynamic Characteristics of Super High-rise Buildings using GB-RAR: A Case Study of the WGC under Construction, China. Appl. Sci. 2020, 10, 808. [CrossRef]

4. Zinno, R.; Artese, S.; Clausi, G.; Magarò, F.; Meduri, S.; Miceli, A.; Venneri, A. Structural Health Monitoring (SHM). Internet Things Smart Urban Ecosyst; Springer: Cham, Switzerland, 2019; pp. 225-249.

5. Li, H.-N.; Ren, L.; Jia, Z.-G.; Yi, T.-H.; Li, D.-S. State-of-the-art in structural health monitoring of large and complex civil infrastructures. J. Civ. Struct. Heal. Monit. 2016, 6, 3-16. [CrossRef] 
6. Kurka, P.R.G.; Cambraia, H.N. Application of a multivariable input-output subspace identification technique in structural analysis. J. Sound Vib. 2008, 312, 461-475. [CrossRef]

7. Rytter, A. Vibration Based Inspection of Civil Engineering Structures. Ph.D. Thesis, Aalborg Univ Denmark, Aalborg, Denmark, 1993.

8. Doebling, S.W.; Farrar, C.R.; Prime, M.B. A summary review of vibration-based damage identification methods. Shock Vib. Dig. 1998, 30, 91-105. [CrossRef]

9. Qiao, L.; Esmaeily, A. An Overview of Signal-Based Damage Detection Methods. Appl. Mech. Mater. 2011, 94-96, 834-851. [CrossRef]

10. Artese, S.; Zinno, R. TLS for Dynamic Measurement of the Elastic Line of Bridges. Appl. Sci. 2020, 10, 1182. [CrossRef]

11. Fan, W.; Qiao, P. Vibration-based damage identification methods: A review and comparative study. Struct. Heal. Monit. 2011, 10, 83-111. [CrossRef]

12. Ozer, E.; Feng, Q.M. Structural Reliability Estimation with Participatory Sensing and Mobile Cyber-Physical Structural Health Monitoring Systems. Appl. Sci. 2019, 9, 2840. [CrossRef]

13. Ljung, L. System Identification; Wiley Online Library: Hoboken, NJ, USA, 1999.

14. Wu, B.; Wu, G.; Yang, C.; He, Y. Damage identification method for continuous girder bridges based on spatially-distributed long-gauge strain sensing under moving loads. Mech. Syst. Signal Process. 2018, 104, 415-435. [CrossRef]

15. Chen, C.-C.; Wu, W.-H.; Liu, C.-Y.; Lai, G. Damage detection of a cable-stayed bridge based on the variation of stay cable forces eliminating environmental temperature effects. Smart Struct. Syst. 2016, 17, 859-880. [CrossRef]

16. Yu, Z.; Xia, H.; Goicolea, J.M.; Xia, C. Bridge damage identification from moving load induced deflection based on wavelet transform and Lipschitz exponent. Int. J. Struct. Stab. Dyn. 2016, 16, 1550003. [CrossRef]

17. Zhu, Y.; Ni, Y.-Q.; Jin, H.; Inaudi, D.; Laory, I. A temperature-driven MPCA method for structural anomaly detection. Eng. Struct. 2019, 190, 447-458. [CrossRef]

18. Cardini, A.J.; Dewolf, J.T. Implementation of a long-term bridge weigh-in-motion system for a steel girder bridge in the interstate highway system. J. Bridge Eng. 2009, 14, 418-423. [CrossRef]

19. Cantero, D.; Karoumi, R.; González, A. The Virtual Axle concept for detection of localised damage using Bridge Weigh-in-Motion data. Eng. Struct. 2015, 89, 26-36. [CrossRef]

20. Gonzalez, I.; Karoumi, R. BWIM aided damage detection in bridges using machine learning. J. Civ. Struct. Heal. Monit. 2015, 5, 715-725. [CrossRef]

21. Kalyankar, R.; Uddin, N. Axle detection on prestressed concrete bridge using bridge weigh-in-motion system. J. Civ. Struct. Heal. Monit. 2017, 7, 191-205. [CrossRef]

22. Xu, X.; Ren, Y.; Huang, Q.; Fan, Z.Y.; Tong, Z.J.; Chang, W.J.; Liu, B. Anomaly detection for large span bridges during operational phase using structural health monitoring data. Smart Mater. Struct. 2020, $29,45029$. [CrossRef]

23. Kroll, A.; Schulte, H. Benchmark problems for nonlinear system identification and control using soft computing methods: Need and overview. Appl. Soft Comput. 2014, 25, 496-513. [CrossRef]

24. Staszewski, W.J. Identification of non-linear systems using multi-scale ridges and skeletons of the wavelet transform. J. Sound Vib. 1998, 214, 639-658. [CrossRef]

25. Qiao, L. Structural Damage Detection Using Signal-Based Pattern Recognition. Ph.D. Thesis, Kansas State University, Manhattan, KS, USA, 2009.

26. Karbhari, V.M.; Guan, H. Sikorsky, C. Operational Modal Analysis for Vibration-based Structural Health Monitoring of Civil Structures. In Structural Health Monitoring of Civil Infrastructure Systems; Woodhead Publishing: Sawston/Cambridge, UK, 2009; pp. 213-259.

27. Runtemund, K.; Cottone, G.; Müller, G. Treatment of arbitrarily autocorrelated load functions in the scope of parameter identification. Comput. Struct. 2013, 126, 29-40. [CrossRef]

28. Pavlov, G.K. Design of Health Monitoring System to Detect Tower Oscilations. Master's Thesis, Technical University of Denmark, Lyngby, Denmark, 2008.

29. Shokravi, H.; Shokravi, H.; Bakhary, N.; Koloor, S.S.R.; Petru, M. Application of the Subspace-based Methods in Health Monitoring of the Civil Structures: A Systematic Review and Meta-analysis. Appl. Sci. 2020. (under review). 
30. Sohn, H.; Farrar, C.R.; Hemez, F.M.; Shunk, D.D.; Stinemates, D.W.; Nadler, B.R.; Czarnecki, J.J. A Review of Structural Health Monitoring Literature: 1996-2001; Los Alamos National Laboratory: Los Alamos, NM, USA, 2003.

31. Shokravi, H.; Shokravi, H.; Bakhary, N.; Koloor, S.S.R.; Petru, M. A Comparative Study of the Data-driven Stochastic Subspace Methods for Health Monitoring of Structures: A Bridge Case Study. Appl. Sci. 2020. (under review).

32. Senthilnathan, K.; Hiremath, C.P.; Naik, N.K.; Guha, A.; Tewari, A. Microstructural damage dependent stiffness prediction of unidirectional CFRP composite under cyclic loading. Compos. Part A Appl. Sci. Manuf. 2017, 100, 118-127. [CrossRef]

33. Yu, Y.; Zou, Y.; Al Hosani, M.; Tian, G. Conductivity Invariance Phenomenon of Eddy Current NDT: Investigation, Verification, and Application. IEEE Trans. Magn. 2017, 53, 1-7. [CrossRef]

34. Alwash, M.; Breysse, D.; Sbartaï, Z.M.; Szilágyi, K.; Borosnyói, A. Factors affecting the reliability of assessing the concrete strength by rebound hammer and cores. Constr. Build. Mater. 2017, 140, 354-363. [CrossRef]

35. Epp, T.; Cha, Y.-J. Wavelet Transform-Based Damage Detection in Reinforced Concrete Using an Air-Coupled Impact-Echo Method. In Structural Health Monitoring \& Damage Detection; Springer: Cham, Switzerland, 2017; Volume 7, pp. 23-25.

36. Davis, A.G.; Ansari, F.; Gaynor, R.D.; Lozen, K.M.; Rowe, T.J.; Caratin, H.; Heidbrink, F.D.; Malhotra, V.M.; Simons, B.P.; Carino, N.J.; et al. Nondestructive Test Methods for Evaluation of Concrete in Structures; American Concrete Institute, ACI: Farmington Hills, MI, USA, 1998.

37. Kaiser, H.; Karbhari, V.M. Non-destructive testing techniques for FRP rehabilitated concrete. I: A critical review. Int. J. Mater. Prod. Technol. 2004, 21, 349-384. [CrossRef]

38. Ettouney, M.M.; Alampalli, S. Infrastructure Health in Civil Engineering: Theory and Components; CRC Press: Boca Raton, FL, USA, 2016; Volume 1.

39. Terlaje, A.; Gould, P.; Dyke, S. An Algorithm and Methodology for Static Response Based Damage Detection in Structural Systems. IEEE Trans. Signal Process. 1994, 8, 2146-2157.

40. Eun, H.C.; Park, S.Y.; Lee, M.S. Static-Based Damage Detection Using Measured Strain and Deflection Data. In Applied Mechanics and Materials; Trans Tech Publications Ltd.: Stafa-Zurich, Switzerland, 2013; Volume 256, pp. 1097-1100.

41. Gul, M.; Catbas, F.N. Structural health monitoring and damage assessment using a novel time series analysis methodology with sensor clustering. J. Sound Vib. 2011, 330, 1196-1210. [CrossRef]

42. Song, G.; Wang, C.; Wang, B. Structural Health Monitoring (SHM) of Civil Structures. Appl. Sci. 2017, 7, 789. [CrossRef]

43. Reynders, E. System identification methods for (operational) modal analysis: Review and comparison. Arch. Comput. Methods Eng. 2012, 19, 51-124. [CrossRef]

44. Ingle, V.; Proakis, J. Digital Signal Processing Using MATLAB; Cengage Learning: Boston, MA, USA, 2011.

45. Bendat, J.S.; Piersol, A.G. Engineering Applications of Correlation and Spectral Analysis; Wiley-Interscience: New York, NY, USA, 1980.

46. Brincker, R.; Zhang, L.; Andersen, P. Modal identification of output-only systems using frequency domain decomposition. Smart Mater. Struct. 2001, 10, 441. [CrossRef]

47. Pioldi, F.; Rizzi, E. A refined Frequency Domain Decomposition tool for structural modal monitoring in earthquake engineering. Earthq. Eng. Eng. Vib. 2017, 16, 627-648. [CrossRef]

48. Khalilinia, H.; Zhang, L.; Venkatasubramanian, V. Fast frequency-domain decomposition for ambient oscillation monitoring. IEEE Trans. Power Deliv. 2015, 30, 1631-1633. [CrossRef]

49. Allemang, R.J.; Brown, D.L. A complete review of the complex mode indicator function (CMIF) with applications. In Proceedings of the ISMA International Conference on Noise and Vibration Engineering, Katholieke Universiteit Leuven, Leuven, Belgium, 18-20 September 2006; Volume 38, pp. 36-44.

50. Guillaume, P.; Verboven, P.; Vanlanduit, S. Frequency-domain maximum likelihood identification of modal parameters with confidence intervals. In Proceedings of the International Seminar on Modal Analysis, Katholieke Universiteit Leuven, Leuven, Belgium, 16 September 1998; Volume 1, pp. 359-366.

51. Peeters, B.; Van der Auweraer, H.; Guillaume, P.; Leuridan, J. The PolyMAX frequency-domain method: A new standard for modal parameter estimation? Shock Vib. 2004, 11, 395-409. [CrossRef] 
52. El-Kafafy, M.; Guillaume, P.; Peeters, B.; Marra, F.; Coppotelli, G. Advanced frequency-domain modal analysis for dealing with measurement noise and parameter uncertainty. In Topics in Modal Analysis I; Springer: New York, NY, USA, 2012; Volume 5, pp. 179-199.

53. Kim, J.; Lynch, J.P. Comparison study of output-only subspace and frequency-domain methods for system identification of base excited civil engineering structures. In Civil Engineering Topics; Springer: New York, NY, USA, 2011; Volume 4, pp. 305-312.

54. Liu, C.W.; Wu, J.Z.; Zhang, Y.G. Review and prospect on modal parameter identification of spatial lattice structure based on ambient excitation. In Applied Mechanics and Materials; Trans Tech Publications Ltd.: Stafa-Zurich, Switzerland, 2011; Volume 94, pp. 1271-1277.

55. Magalhães, F.; Caetano, E.; Cunha, Á. Challenges in the application of stochastic modal identification methods to a cable-stayed bridge. J. Bridge Eng. 2007, 12, 746-754. [CrossRef]

56. Redif, S.; Weiss, S.; McWhirter, J.G. Relevance of polynomial matrix decompositions to broadband blind signal separation. Signal Process. 2017, 134, 76-86. [CrossRef]

57. Cunha, A.; Caetano, E.; Magalhaes, F.; Moutinho, C. Recent perspectives in dynamic testing and monitoring of bridges. Struct. Control Heal. Monit. 2013, 20, 853-877. [CrossRef]

58. James, G.H.; Carne, T.G.; Lauffer, J.P. The Natural Excitation Technique (NExT) for Modal Parameter Extraction from Operating Wind Turbines; Sandia National Labs: Albuquerque, NM, USA, 1993.

59. Brown, D.L.; Allemang, R.J.; Zimmerman, R.; Mergeay, M. Parameter estimation techniques for modal analysis. SAE Technical paper. SAE Trans. 1979, 13, 176-186.

60. Vold, H.; Kundrat, J.; Rocklin, G.T.; Russell, R. A Multi-Input Modal Estimation Algorithm for Mini-Computers; SAE Technical Paper; SAE: Warrendale, PA, USA, 1982.

61. Juang, J.-N.; Pappa, R.S. An eigensystem realization algorithm for modal parameter identification and model reduction. J. Guid. Control. Dyn. 1985, 8, 620-627. [CrossRef]

62. Juang, J.-N.; Cooper, J.E.; Wright, J.R. An eigensystem realization algorithm using data correlations (ERA/DC) for modal parameter identification. Control Adv. Technol. 1988, 4, 5-14.

63. Zhang, L.; Yao, Y.; Lu, M. An improved time domain polyreference method for modal identification. Mech. Syst. Signal Process. 1987, 1, 399-413. [CrossRef]

64. Zhang, L. An overview of major developments and issues in modal identification. In Proceedings of the 22nd International Modal Analysis Conference (IMAC), Detroit, MI, USA, 12 August 2004; pp. 1-8.

65. Fukuzono, K. Investigation of Multiple-Reference Ibrahim Time Domain Modal Parameter Estimation Technique. Ph. D. Thesis, University of Cincinnati, Cincinnati, OH, USA, 1986.

66. Juang, J.-N. Applied System Identification; Prentice Hall: Englewood Cliffs, NJ, USA, 1994.

67. Chang, M.; Pakzad, S.N. Observer Kalman Filter Identification for Output-Only Systems Using Interactive Structural Modal Identification Toolsuite. J. Bridge Eng. 2013, 19, 4014002. [CrossRef]

68. Vicario, F.; Phan, M.Q.; Betti, R.; Longman, R.W. Output-only observer/Kalman filter identification (O3KID). Struct. Control Heal. Monit. 2014, 22, 847-872. [CrossRef]

69. Cole, Jr. On-line Failure Detection and Damping Measurement of Aerospace Structures by Random Decrement Signatures; NASA: Washington, DC, USA, 1973; Volume 37.

70. Brincker, R.; Rodrigues, J.; Brincker, R. Application of the random decrement technique in operational modal analysis. In Proceedings of the 1st International Operational Modal Analysis Conference (IOMAC), Aalborg Universitet, Aalborg, Denmark, 26-27 April 2005.

71. Ljung, L. System Identification: Theory for the User, PTR Prentice Hall Information and System Sciences Series; Prentice Hall: Upper Saddle River, NJ, USA, 1999.

72. Sohn, H.; Czarnecki, J.A.; Farrar, C.R. Structural health monitoring using statistical process control. J. Struct. Eng. 2000, 126, 1356-1363. [CrossRef]

73. Sohn, H.; Farrar, C.R. Damage diagnosis using time series analysis of vibration signals. Smart Mater. Struct. 2011, 10, 446-451. [CrossRef]

74. Bodeux, J.B.; Golinval, J.C. Application of ARMAV models to the identification and damage detection of mechanical and civil engineering structures. Smart Mater. Struct. 2001, 10, 479-489. [CrossRef]

75. Fasel, T.R.; Gregg, S.W.; Johnson, T.J.; Farrar, C.R.; Sohn, H. Experimental modal analysis and damage detection in a simulated three story building. In Proceedings of the 20th International Modal Analysis Conference, Los Angeles, CA, USA, 4-7 February 2002; pp. 122-135. 
76. Huang, C.S. Structural identification from ambient vibration measurement using the multivariate AR model. J. Sound Vib. 2001, 241, 337-359. [CrossRef]

77. Hung, C.F.; Ko, W.J. Identification of modal parameters from measured output data using vector backward autoregressive model. J. Sound Vib. 2002, 256, 249-270. [CrossRef]

78. Bodeux, J.B.; Golinval, J.C. Modal identification and damage detection using the data-driven stochastic subspace and ARMAV methods. Mech. Syst. Signal Process. 2003, 17, 83-89. [CrossRef]

79. Bertha, M.; Golinval, J.-C. Identification of non-stationary dynamical systems using multivariate ARMA models. Mech. Syst. Signal Process. 2017, 88, 166-179. [CrossRef]

80. Nair, K.K.; Kiremidjian, A.S.; Law, K.H. Time series-based damage detection and localization algorithm with application to the ASCE benchmark structure. J. Sound Vib. 2006, 291, 349-368. [CrossRef]

81. Carden, E.P.; Brownjohn, J.M.W. ARMA modelled time-series classification for structural health monitoring of civil infrastructure. Mech. Syst. Signal Process. 2008, 22, 295-314. [CrossRef]

82. Nair, K.K.; Kiremidjian, A.S. Time series based structural damage detection algorithm using Gaussian mixtures modeling. J. Dyn. Syst. Meas. Control 2007, 129, 285. [CrossRef]

83. Omenzetter, P.; Brownjohn, J. Application of time series analysis for bridge monitoring. Smart Mater. Struct. 2006, 15, 129-138. [CrossRef]

84. Spiridonakos, M.D.; Poulimenos, A.G.; Fassois, S.D. Output-only identification and dynamic analysis of time-varying mechanical structures under random excitation: A comparative assessment of parametric methods. J. Sound Vib. 2010, 329, 768-785. [CrossRef]

85. Gil, P.; Santos, F.; Palma, L.; Cardoso, A. Recursive subspace system identification for parametric fault detection in nonlinear systems. Appl. Soft Comput. 2015, 37, 444-455. [CrossRef]

86. Brincker, R.; Andersen, P. Understanding stochastic subspace identification. In Proceedings of the 24th IMAC, St. Louis, MO, USA, 30 January-2 February 2006; p. 126.

87. Gomez, H.C. System Identification of Highway Bridges using Long-Term Vibration Monitoring Data. Ph.D. Thesis, University of California, Irvine, CA, USA, 2012.

88. Larimore, W.E. Canonical variate analysis in identification, filtering, and adaptive control. In Proceedings of the 29th IEEE Conference on Decision and Control, Honolulu, HI, USA, 5-7 December 1990; pp. 596-604.

89. Akaike, H. Markovian representation of stochastic processes by canonical variables. SIAM J. Control 1975, 13, 162-173. [CrossRef]

90. Verhaegen, M. Identification of the deterministic part of MIMO state space models given in innovations form from input-output data. Automatica 1994, 30, 61-74. [CrossRef]

91. Van Overschee, P.; De Moor, B.L. Subspace Identification for Linear Systems: Theory-Implementation-Applications; Springer Science \& Business Media: Berlin, Germany, 2012.

92. Shokravi, H.; Bakhary, N.H. Comparative analysis of different weight matrices in subspace system identification for structural health monitoring. IOP Conf. Ser. Mater. Sci. Eng. 2017, 271, 12092. [CrossRef]

93. Van Overschee, P.; De Moor, B.; Dehandschutter, W.; Swevers, J. A subspace algorithm for the identification of discrete time frequency domain power spectra. Automatica 1997, 33, 2147-2157. [CrossRef]

94. Basseville, M.; Abdelghani, M.; Benveniste, A. Subspace-based fault detection algorithms for vibration monitoring. Automatica 2000, 36, 101-109. [CrossRef]

95. Yan, A.-M.M.; De Boe, P.; Golinval, J.-C.C. Structural damage diagnosis by Kalman model based on stochastic subspace identification. Struct. Heal. Monit. 2004, 3, 103-119. [CrossRef]

96. Yan, A.-M.; Golinval, J.-C. Null subspace-based damage detection of structures using vibration measurements. Mech. Syst. Signal Process. 2006, 20, 611-626. [CrossRef]

97. Reynders, E.; De Roeck, G. Reference-based combined deterministic-stochastic subspace identification for experimental and operational modal analysis. Mech. Syst. Signal Process. 2008, 22, 617-637. [CrossRef]

98. Urgessa, G.S. Vibration properties of beams using frequency-domain system identification methods. J. Vib. Control 2010, 17, 1287-1294. [CrossRef]

99. Nguyen, V.H.; Golinval, J.-C. Fault detection based on kernel principal component analysis. Eng. Struct. 2010, 32, 3683-3691. [CrossRef]

100. Goursat, M.; Döhler, M.; Mevel, L.; Andersen, P. Crystal clear SSI for operational modal analysis of aerospace vehicles. In Structural Dynamics; Springer: New York, NY, USA, 2011; Volume 3, pp. 1421-1430. 
101. Loh, C.H.; Weng, J.H.; Liu, Y.C.; Lin, P.Y.; Huang, S.K. Structural damage diagnosis based on on-line recursive stochastic subspace identification. Smart Mater. Struct. 2011, 20, 34-55. [CrossRef]

102. Zhang, G.; Tang, B.; Tang, G. An improved stochastic subspace identification for operational modal analysis. Measurement 2012, 45, 1246-1256. [CrossRef]

103. Chao, S.-H.; Loh, C.-H.; Weng, J.-H. Application of higher order SVD to vibration-based system identification and damage detection. In Sensors and Smart Structures Technologies for Civil, Mechanical, and Aerospace Systems; International Society for Optics and Photonics: Bellingham, WA, USA, 2012; Volume 8345, p. 834525. [CrossRef]

104. Döhler, M.; Andersen, P.; Mevel, L. Operational modal analysis using a fast stochastic subspace identification method. In Topics in Modal Analysis I; Springer: New York, NY, USA, 2012; Volume 5, pp. 19-24.

105. Hong, A.L.; Ubertini, F.; Betti, R. New Stochastic Subspace Approach for System Identification and Its Application to Long-Span Bridges. J. Eng. Mech. 2013, 139, 724-736. [CrossRef]

106. Basseville, M.; Mevel, L.; Goursat, M. Statistical model-based damage detection and localization: Subspace-based residuals and damage-to-noise sensitivity ratios. J. Sound Vib. 2004, 275, 769-794. [CrossRef]

107. Yu, D.-J.; Ren, W.-X. EMD-based stochastic subspace identification of structures from operational vibration measurements. Eng. Struct. 2005, 27, 1741-1751. [CrossRef]

108. Zhang, Z.; Fan, J.; Hua, H. Simulation and experiment of a blind subspace identification method. J. Sound Vib. 2008, 311, 941-952. [CrossRef]

109. Carden, E.P.; Brownjohn, J.M.W. Fuzzy Clustering of Stability Diagrams for Vibration-Based Structural Health Monitoring. Comput. Civ. Infrastruct. Eng. 2008, 23, 360-372. [CrossRef]

110. Balmès, E.; Basseville, M.; Bourquin, F.; Mevel, L.; Nasser, H.; Treyssède, F. Merging sensor data from multiple temperature scenarios for vibration monitoring of civil structures. Struct. Heal. Monit. 2008, 7, 129-142. [CrossRef]

111. Basseville, M.; Bourquin, F.; Mevel, L.; Nasser, H.; Treyssède, F. Handling the temperature effect in vibration monitoring: Two subspace-based analytical approaches. J. Eng. Mech. 2010, 136, 367. [CrossRef]

112. Ren, W.X.; Lin, Y.Q.; Fang, S.E. Structural damage detection based on stochastic subspace identification and statistical pattern recognition: I. Theory. Smart Mater. Struct. 2011, 20, 115009. [CrossRef]

113. Lin, Y.Q.; Ren, W.X.; Fang, S.E. Structural damage detection based on stochastic subspace identification and statistical pattern recognition: II. Experimental validation under varying temperature. Smart Mater. Struct. 2011, 20, 115010. [CrossRef]

114. Li, Z.; Chang, C.C. Tracking of structural dynamic characteristics using recursive stochastic subspace identification and instrumental variable technique. J. Eng. Mech. 2011, 138, 591-600. [CrossRef]

115. Loendersloot, R.; Schiphorst, F.B.A.; Basten, T.G.H.; Tinga, T. Application of SHM Using an Autonomous Sensor Network; DEStech Publications, Inc: Lancaster, PA, USA, 2013.

116. Miguel, L.F.F.; Lopez, R.H.; Miguel, L.F.F. A hybrid approach for damage detection of structures under operational conditions. J. Sound Vib. 2013, 332, 4241-4260. [CrossRef]

117. Chao, S.-H.; Loh, C.-H.; Tseng, M.-H. Structural damage assessment using output-only measurement: Localization and quantification. J. Intell. Mater. Syst. Struct. 2013, 25, 1097-1106. [CrossRef]

118. Reynders, E.; Maes, K.; Lombaert, G.; De Roeck, G. Uncertainty quantification in operational modal analysis with stochastic subspace identification: Validation and applications. Mech. Syst. Signal Process. 2016, 66, 13-30. [CrossRef]

119. Ozcelik, O.; Misir, I.S.; Amaddeo, C.; Yucel, U.; Durmazgezer, E. Modal Identification Results of Quasi-statically Tested RC Frames at Different Damage Levels. In Topics in Modal Analysis; Springer: Cham, Switzerland, 2015; Volume 10, pp. 215-226.

120. Magalhães, F.; Reynders, E.; Cunha, Á.; De Roeck, G. Online automatic identification of modal parameters of a bridge using the p-LSCF method. In Proceedings of the IOMAC, Ancona, Italy, 4-6 May 2009.

121. Wang, S.Q.; Zhang, Y.T.; Feng, Y.X. Comparative study of output-based modal identification methods using measured signals from an offshore platform. In ASME 2010 29th International Conference on Ocean, Offshore and Arctic Engineering; American Society of Mechanical Engineers: New York, NY, USA, 2010; pp. 561-567.

122. Moaveni, B.; He, X.; Conte, J.P.; Restrepo, J.I.; Panagiotou, M. System identification study of a 7-story full-scale building slice tested on the UCSD-NEES shake table. J. Struct. Eng. 2010, 137, 705-717. [CrossRef]

123. Cunha, A.; Caetano, E.; Ribeiro, P.; Müller, G. Vibration-based SHM of a centenary bridge: A comparative study between two different automated OMA techniques. Preservation 2011, 1, 12. 
124. Ceravolo, R.; Abbiati, G. Time domain identification of structures: Comparative analysis of output-only methods. J. Eng. Mech. 2012, 139, 537-544. [CrossRef]

125. Sohn, H. A Bayesian Probabilistic Approach to Damage Detection for Civil Structures. Dep. Civ. Environ. Eng. 1998.

126. Peeters, B.; De Roeck, G. Reference-based stochastic subspace identification for output-only modal analysis. Mech. Syst. Signal Process. 1999, 13, 855-878. [CrossRef]

127. Pridham, B.A.; Wilson, J.C. A study of damping errors in correlation-driven stochastic realizations using short data sets. Probabilistic Eng. Mech. 2003, 18, 61-77. [CrossRef]

128. Pan, Q. System identification of constructed civil engineering structures and uncertainty. Ph.D. Thesis, Drexel University, Philadelphia, PA, USA, 2007.

129. Benveniste, A.; Mevel, L. Nonstationary consistency of subspace methods. Autom. Control IEEE Trans. 2007, 52, 974-984. [CrossRef]

130. Reynders, E.; Pintelon, R.; De Roeck, G. Uncertainty bounds on modal parameters obtained from stochastic subspace identification. Mech. Syst. Signal Process. 2008, 22, 948-969. [CrossRef]

131. Brasiliano, A.; Doz, G.; Brito, J.L.; Pimentel, R. Role of non-metallic components on the dynamic behavior of composite footbridges. In Proceedings of the Third International Conference-Footbridges, Porto, Portugal, 2-4 July 2008; pp. 501-522.

132. Alıcıoğlu, B.; Luş, H. Ambient vibration analysis with subspace methods and automated mode selection: Case studies. J. Struct. Eng. 2008, 134, 1016-1029. [CrossRef]

133. Marchesiello, S.; Bedaoui, S.; Garibaldi, L.; Argoul, P. Time-dependent identification of a bridge-like structure with crossing loads. Mech. Syst. Signal Process. 2009, 23, 2019-2028. [CrossRef]

134. Balmès, É.; Basseville, M.; Mevel, L.; Nasser, H. Handling the temperature effect in vibration monitoring of civil structures: A combined subspace-based and nuisance rejection approach. Control Eng. Pract. 2009, 17, 80-87.

135. Wang, J.; Sano, A.; Chen, T.; Huang, B. Identification of Hammerstein systems without explicit parameterisation of non-linearity. Int. J. Control 2009, 82, 937-952. [CrossRef]

136. Magalhães, F.; Cunha, Á.; Caetano, E.; Brincker, R. Damping estimation using free decays and ambient vibration tests. Mech. Syst. Signal Process. 2010, 24, 1274-1290. [CrossRef]

137. Döhler, M.; Reynders, E.; Magalhaes, F.; Mevel, L.; De Roeck, G.; Cunha, A. Pre-and post-identification merging for multi-setup OMA with covariance-driven SSI. In Dynamics of Bridges; Springer: New York, NY, USA, 2011; Volume 5, pp. 57-70.

138. Carden, E.P.; Mita, A. Challenges in developing confidence intervals on modal parameters estimated for large civil infrastructure with stochastic subspace identification. Struct. Control Heal. Monit. 2011, 18, 53-78. [CrossRef]

139. Döhler, M.; Mevel, L. Modular subspace-based system identification from multi-setup measurements. IEEE Trans. Automat. Contr. 2012, 57, 2951-2956. [CrossRef]

140. Döhler, M.; Lam, X.-B.; Mevel, L. Uncertainty quantification for modal parameters from stochastic subspace identification on multi-setup measurements. Mech. Syst. Signal Process. 2013, 36, 562-581. [CrossRef]

141. Loh, C.H.; Chen, M.C. Modeling of environmental effects for vibration-based shm using recursive stochastic subspace identification analysis. In Key Engineering Materials; Trans Tech Publications Ltd.: Stafa-Zurich, Switzerland, 2013; Volume 558, pp. 52-64.

142. Brehm, M.; Zabel, V.; Bucher, C. Optimal reference sensor positions using output-only vibration test data. Mech. Syst. Signal Process. 2013, 41, 196-225. [CrossRef]

143. Cara, F.J.; Juan, J.; Alarcón, E.; Reynders, E.; De Roeck, G. Modal contribution and state space order selection in operational modal analysis. Mech. Syst. Signal Process. 2013, 38, 276-298. [CrossRef]

144. Ashari, A.E.; Mevel, L. Auxiliary input design for stochastic subspace-based structural damage detection. Mech. Syst. Signal Process. 2013, 34, 241-258. [CrossRef]

145. Tondreau, G.; Deraemaeker, A. Numerical and experimental analysis of uncertainty on modal parameters estimated with the stochastic subspace method. J. Sound Vib. 2014, 333, 4376-4401. [CrossRef]

146. Rainieri, C.; Fabbrocino, G. Influence of model order and number of block rows on accuracy and precision of modal parameter estimates in stochastic subspace identification. Int. J. Lifecycle Perform Eng. 10 2014, 1, 317-334. [CrossRef] 
147. Cho, S.; Park, J.-W.; Sim, S.-H. Decentralized system identification using stochastic subspace identification for wireless sensor networks. Sensors 2015, 15, 8131-8145. [CrossRef]

148. Markovsky, I. The most powerful unfalsified model for data with missing values. Syst. Control Lett. 2016, 95, 53-61. [CrossRef]

149. Banfi, L.; Carassale, L. Uncertainties in an Application of Operational Modal Analysis. In Model Validation and Uncertainty Quantification; Springer: Cham, Switzerland, 2016; Volume 3, pp. 107-115.

150. Spiridonakos, M.D.; Chatzi, E.N.; Sudret, B. Polynomial Chaos Expansion Models for the Monitoring of Structures under Operational Variability. ASCE-ASME J. Risk Uncertain. Eng. Syst. Part A Civ. Eng. 2016, 2, B4016003. [CrossRef]

151. Huynh, T.C.; Park, J.H.; Kim, J.T. Structural identification of cable-stayed bridge under back-to-back typhoons by wireless vibration monitoring. Measurement 2016, 88, 385-401. [CrossRef]

152. Li, D.; Ren, W.-X.; Hu, Y.-D.; Yang, D. Operational modal analysis of structures by stochastic subspace identification with a delay index. Struct. Eng. Mech. 2016, 59, 187-207. [CrossRef]

153. Pepe, M.; Costantino, D.; Restuccia Garofalo, A. An Efficient Pipeline to Obtain 3D Model for HBIM and Structural Analysis Purposes from 3D Point Clouds. Appl. Sci. 2020, 10, 1235. [CrossRef]

154. Kovačević, S.M.; Bačić, M.; Stipanović, I.; Gavin, K. Categorization of the Condition of Railway Embankments Using a Multi-Attribute Utility Theory. Appl. Sci. 2019, 9, 5089. [CrossRef]

155. Yang, K.; Ding, Y.; Sun, P.; Zhao, H.; Geng, F. Modeling of Temperature Time-Lag Effect for Concrete Box-Girder Bridges. Appl. Sci. 2019, 9, 3255. [CrossRef]

156. Vanlanduit, S.; Parloo, E.; Cauberghe, B.; Guillaume, P.; Verboven, P. A robust singular value decomposition for damage detection under changing operating conditions and structural uncertainties. J. Sound Vib. 2005, 284, 1033-1050. [CrossRef]

157. Naseralavi, S.S.; Salajegheh, E.; Fadaee, M.J.; Salajegheh, J. A novel sensitivity-based method for damage detection of structures under unknown periodic excitations. J. Sound Vib. 2014, 333, 2776-2803. [CrossRef]

158. Döhler, M.; Hille, F. Subspace-based damage detection on steel frame structure under changing excitation. In Structural Health Monitoring; Springer: Cham, Switzerland, 2014; Volume 5, pp. 167-174.

159. Banan, M.R.; Mehdi-Pour, Y. Detection and assessment of damage in 2D structures using measured modal response. J. Sound Vib. 2007, 306, 803-817. [CrossRef]

160. Siegert, D.; Döhler, M.; Mekki OBen Mevel, L.; Goursat, M.; Toutlemonde, F. Vibration monitoring of a small span composite bridge. In Structural Dynamics; Springer: New York, NY, USA, 2011; Volume 3, pp. 53-61.

161. Huang, M.C.; Wang, Y.P.; Chang, M.L. Damage Detection of Structures Identified with Deterministic-Stochastic Models Using Seismic Data. Sci. World J. 2014, 2014. [CrossRef]

162. Kim, J.; Lynch, J.P. Subspace system identification of support excited structures-part II: Gray-box interpretations and damage detection. Earthq. Eng. Struct. Dyn. 2012, 41, 2253-2271. [CrossRef]

163. Wang, Y.P.; Lin, Y.T.; Huang, G. Damage Localization of Output-Only Frame Systems Using Stochastic Subspace Identification. Adv. Mater. Res. 2012, 3, 1352-1359. [CrossRef]

164. Moaveni, B.; Stavridis, A.; Shing, P.B. System identification of a three-story infilled RC frame tested on the UCSD-NEES shake table. In Dynamics of Civil Structures; Springer: New York, NY, USA, 2011; Volume 4, pp. 135-143.

165. Weng, J.H.; Loh, C.H.; Yang, J.N. Experimental Study of Damage Detection by Data-Driven Subspace Identification and Finite-Element Model Updating. J. Struct. Eng. 2009, 135, 1533-1544. [CrossRef]

166. Karami, K.; Akbarabadi, S. Developing a Smart Structure Using Integrated Subspace-Based Damage Detection and Semi-Active Control. Comput. Civ. Infrastruct. Eng. 2016, 31, 887-903. [CrossRef]

167. Belleri, A.; Moaveni, B.; Restrepo, J.I. Damage assessment through structural identification of a three-story large-scale precast concrete structure. Earthq. Eng. Struct. Dyn. 2014, 43, 61-76. [CrossRef]

168. Shinagawa, Y.; Mita, A. Verification of structural health assessment method using full-scale collapse test of four-story steel building. In Key Engineering Materials; Trans Tech Publications Ltd.: Stäfa, Switzerland, 2013; pp. 174-183. [CrossRef]

169. Zhou, W.; Li, H.; Mevel, L.; Döhler, M.; Lam, X.B.; Mao, C.; Ou, J. Seismic Damage Assessment for a Residential Masonry Building Using Aftershock Monitoring of Wenchuan Earthquake. In Proceedings of the 24th International Conference on Noise and Vibration Engineering (ISMA2010), Leuven, Belgium, 20 September 2010; pp. 773-782. 
170. Yoshimoto, R.; Mita, A.; Okada, K. Damage detection of base-isolated buildings using multi-input multi-output subspace identification. Earthq. Eng. Struct. Dyn. 2005, 34, 307-324. [CrossRef]

171. Allahdadian, S.; Ventura, C.E.; Andersen, P.; Mevel, L.; Dohler, M. Sensitivity Evaluation of Subspace-Based Damage Detection Method to Different Types of Damage. In Structural Health Monitoring and Damage Detection; Springer: Cham, Switzerland, 2015; pp. 11-18. [CrossRef]

172. Dohler, M.; Hille, F.; Mevel, L.; Rucker, W. Structural health monitoring with statistical methods during progressive damage test of S101 Bridge. Eng. Struct. 2014, 69, 183-193. [CrossRef]

173. Deraemaeker, A.; Reynders, E.; De Roeck, G.; Kullaa, J. Vibration-based structural health monitoring using output-only measurements under changing environment. Mech. Syst. Signal Process. 2008, 22, 34-56. [CrossRef]

174. Hu, W.H.; Moutinho, C.; Caetano, E.; Magalhaes, F.; Cunha, A. Continuous dynamic monitoring of a lively footbridge for serviceability assessment and damage detection. Mech. Syst. Signal Process. 2012, 33, $38-55$. [CrossRef]

175. Loh, C.-H.H.; Chao, S.-H.H. Centralized vs. Pattern-level Feature Extraction for Structural Damage Detection. Theor. Appl. Mech. 2014, 79, 479-489. [CrossRef]

176. Mevel, L.; Goursat, M. Stochastic subspace-based structural identification and damage detection and localisation - Application to the Z24 bridge benchmark. Mech. Syst. Signal Process. 2003, 17, 143-151. [CrossRef]

177. Kullaa, J. Damage detection of the Z24 bridge using control charts. Mech. Syst. Signal Process. 2003, 17, 163-170. [CrossRef]

178. Reynders, E.; Wursten, G.; De Roeck, G. Output-only structural health monitoring in changing environmental conditions by means of nonlinear system identification. Struct. Heal. Monit. Int. J. 2014, 13, 82-93. [CrossRef]

179. Nguyen, V.H.; Mahowald, J.; Maas, S.; Golinval, J.-C. Use of time-and frequency-domain approaches for damage detection in civil engineering structures. Shock Vib. 2014, 2014. [CrossRef]

180. Cruz, P.J.S.; Salgado, R. Performance of Vibration-Based Damage Detection Methods in Bridges. Comput. Civ. Infrastruct. Eng. 2009, 24, 62-79. [CrossRef]

181. Nigro, M.B.; Pakzad, S.N.; Dorvash, S. Localized structural damage detection: A change point analysis. Comput. Civ. Infrastruct. Eng. 2014, 29, 416-432. [CrossRef]

182. Döhler, M.; Andersen, P.; Mevel, L. Variance computation of modal parameter estimates from UPC subspace identification. Irnia 2017, 16, 416-432.

183. Zhou, Y.; Prader, J.; Weidner, J.; Moon, F.; Aktan, A.E.; Zhang, J.; Yi, W.J. Structural Identification Study of a Steel Multi-Girder Bridge Based on Multiple Reference Impact Test. Int. Symp. Innov. Sustain. Struct. Civ. Eng. 2013, 12, 315-356.

184. Hu, W.-H.; Cunha, Á.; Caetano, E.; Magalhães, F.; Moutinho, C. LabVIEW toolkits for output-only modal identification and long-term dynamic structural monitoring. Struct. Infrastruct. Eng. 2010, 6, 557-574. [CrossRef]

185. Chang, M.; Pakzad, S.N.; Leonard, R. Modal identification using smit. In Topics on the Dynamics of Civil Structures; Springer: New York, NY, USA, 2012; Volume 1, pp. 221-228.

186. Goursat, M.; Mevel, L. COSMAD: Identification and diagnosis for mechanical structures with Scilab. In Proceedings of the 2008 IEEE International Conference on Computer-Aided Control Systems, San Antonio, TX, USA, 3-5 September 2008; pp. 353-358.

187. Hoofar, S.; Hooman, S.; Norhisham, B.; Heidarrezaei, M.; Koloor, S.S.R.; Petru, M. Vehicle-assisted techniques for health monitoring of bridges. Sensors (Basel) 2020. (Under review).

188. Shokravi, H.; Shokravi, H.; Bakhary, N.; Heidarrezaei, M.; Koloor, S.R.K.; Petru, M. A review on vehicle classification methods and the potential of using smart-vehicle-assisted techniques. Sensors (Basel) 2020. (under review).

(C) 2020 by the authors. Licensee MDPI, Basel, Switzerland. This article is an open access article distributed under the terms and conditions of the Creative Commons Attribution (CC BY) license (http://creativecommons.org/licenses/by/4.0/). 